Article

\title{
Assessment of Land Use-Cover Changes and Successional Stages of Vegetation in the Natural Protected Area Altas Cumbres, Northeastern Mexico, Using Landsat Satellite Imagery
}

\author{
Uriel Jeshua Sánchez-Reyes ${ }^{1}$, Santiago Niño-Maldonado ${ }^{2}$, Ludivina Barrientos-Lozano ${ }^{1, *}$ (D) \\ and Jacinto Treviño-Carreón ${ }^{2}$ \\ 1 Instituto Tecnológico de Ciudad Victoria, Boulevard Emilio Portes Gil No. 1301, C.P. 87010 Ciudad Victoria, \\ Tamaulipas, Mexico; uriel_elf3@hotmail.com \\ 2 Centro Universitario Victoria, Facultad de Ingeniería y Ciencias, Universidad Autónoma de Tamaulipas, \\ C.P. 87149 Ciudad Victoria, Tamaulipas, Mexico; coliopteranino@hotmail.com (S.N.-M.); \\ jatrevino@docentes.uat.edu.mx (J.T.-C.) \\ * Correspondence: ludivinab@yahoo.com; Tel.: +52-834-153-2000 (ext. 325)
}

Academic Editors: Parth Sarathi Roy and Lars T. Waser

Received: 20 May 2017; Accepted: 8 July 2017; Published: 11 July 2017

\begin{abstract}
Loss of vegetation cover is a major factor that endangers biodiversity. Therefore, the use of geographic information systems and the analysis of satellite images are important for monitoring these changes in Natural Protected Areas (NPAs). In northeastern Mexico, the Natural Protected Area Altas Cumbres (NPAAC) represents a relevant floristic and faunistic patch on which the impact of loss of vegetation cover has not been assessed. This work aimed to analyze changes of land use and coverage (LULCC) over the last 42 years on the interior and around the exterior of the area, and also to propose the time of succession for the most important types of vegetation. For the analysis, LANDSAT satellite images from 1973, 1986, 2000, 2005 and 2015 were used, they were classified in seven categories through a segmentation and maximum likelihood analysis. A cross-tabulation analysis was performed to determine the succession gradient. Towards the interior of the area, a significant reduction of tropical vegetation and, to a lesser extent, temperate forests was found, as well as an increase in scrub cover from 1973 to 2015. In addition, urban and vegetation-free areas, as well as modified vegetation, increased to the exterior. Towards the interior of the NPA, the processes of perturbation and recovery were mostly not linear, while in the exterior adjacent area, the presence of secondary vegetation with distinct definite time of succession was evident. The analysis carried out is the first contribution that evaluates LULCC in this important NPA of northeastern Mexico. Results suggest the need to evaluate the effects of these modifications on species.
\end{abstract}

Keywords: disturbance; land use and cover change; Landsat; vegetation; secondary succession; chronosequence; Natural Protected Area; Mexico; Tamaulipas

\section{Introduction}

Disturbance is considered to be any event that abruptly changes the environmental conditions of the habitat [1]. It can be due to a variety of causes, both anthropogenic and natural, including forest fires, urbanization, and land modification as a result of intense agricultural and livestock activities [2]. These factors modify the structure of vegetation, and cause the loss of original plant cover [3-5]. In this sense, land use and land cover change (LULCC) is one of the main factors that has caused an accelerated global loss of biodiversity in recent years. The specific effects of these disturbances at local or microhabitat scales are very important on species communities [6]. 
A recent, effective, and widely used method for detecting and quantifying LULCC is remote sensing [7], and the implementation of geographic information systems through the analysis of satellite images, which allows the detection of temporary patterns of change [3,4,8,9], and even their prediction [10-13]. At present, free availability and easy access to a large amount of geographic data and satellite imagery have permitted this type of analysis to increase considerably $[3,8,9,14-19]$. However, a very important aspect to consider when conducting such assessments is the natural process of secondary succession and the recovery of vegetation after a disturbance event. In this sense, analysis using satellite images to evaluate change of vegetation cover between a time $\mathrm{A}$ and a time $\mathrm{B}$ does not allow us to know the processes of transition or persistence of the vegetation occurring within that time interval, independently of the route of succession that is present. That is, the persistence of a type of cover between the initial stage $A$ and the final stage $B$ does not consider that the current vegetation at time B could present several stages of disturbance and recovery, a fact that is more accentuated in studies that include long periods of time. An alternative is the analysis of multitemporal satellite images, whose importance for detection of disturbances, conservation and habitat monitoring has been previously explored $[20,21]$. So, the reduction in time intervals provides a more precise delimitation of the recovery time or succession of the current vegetation, and also allows to detect the presence of secondary vegetation cover [22,23].

In Mexico, deforestation is one of the most important problems in environmental policy. In recent years, the original vegetation has been dramatically reduced, due mainly to an increase in LULCC, which accelerates the rate of deforestation [24]. This has led to a growing number of investigations that use geographic information systems and satellite imagery for analysis of natural vegetation disturbance, as well as the monitoring and quantification of land use change [12,25-27]. The implementation of these analyses, along with the establishment of Natural Protected Areas (NPAs), represents a strategy aimed at containing modifications in vegetation cover in the country $[28,29]$. The NPAs in Mexico embody more than 19 million hectares, representing $9.85 \%$ of the country's land area [30]. Some of these NPAs have recently been evaluated for their effectiveness in minimizing LULCC [27,31]. It has been shown that the NPAs are not always effective [29,32], since they continue to be modified despite having some protection status. This is largely because of the misapplication of economic policies or the lack of management plans [33,34]. As a whole, these anthropogenic disturbances can affect the integrity of ecological processes, ecosystem functioning and conservation of biodiversity in NPAs [35]. Moreover, LULCC is one of the most important and stressful factors on ecosystems close to urban areas [11]. Therefore, urbanization and modification of external or adjacent areas to the NPAs generate important consequences and effects on the processes that occur towards the interior, since a significant proportion of the habitats and resources that help the functioning of the NPAs are located outside its limits, in unprotected areas [31,36,37].

Overall, administrative issues, poor financing, and accelerated urban growth in adjacent areas are factors that endanger biodiversity in NPAs [34]. Additionally, the lack of analyses that consider multitemporal stages to define the time of succession of vegetation in these zones is evident. Accordingly, it is important to continue with the evaluation and monitoring of the current patterns of LULCC in Mexican NPAs. The Natural Protected Area Altas Cumbres (NPAAC) in Northeastern Mexico is a key area for biodiversity conservation and ecosystem processes, as it is part of a natural biological corridor in the Sierra Madre Oriental. Furthermore, this NPA, because of its biological diversity, embraces one of the 15 panbiogeographical nodes proposed for Mexico [38], as well as several spots with high and extreme priority for conservation [39]. However, the increase of population and industrialization in Mexico during the 60s-80s [40], the deforestation rate expansion (1990 to 2000) [34], the official government decree of NPA status in 1997 [41], the late establishment of an official management plan in 2015 [33,42], and its proximity to an important urban area suggest that the integrity of the major vegetation types in the NPAAC could be compromised. Based on the above, we hypothesized that the highest percentages of LULCC may have occurred within the period 1973-2000, while the official NPA decree in 1997 would lead to a decrease in changes starting in 2000. This work 
aimed to: (1) delimit the main categories of land use-cover in 1973, 1986, 2000, 2005 and 2015 in the NPAAC and its adjacent areas based on Landsat satellite images; (2) quantify the proportion of area modified or persistent for each category between the different temporal stages; and, based on this, (3) propose the time of succession or recovery for the most important types of vegetation in the NPAAC and its adjacent areas.

\section{Materials and Methods}

\subsection{Description of the Study Area}

The NPAAC was decreed as a Special Area Subject to Ecological Conservation on 19 November 1997 [41]. It is located westward of Ciudad Victoria, within the municipality of Victoria in the state of Tamaulipas, northeastern Mexico (Figure 1).
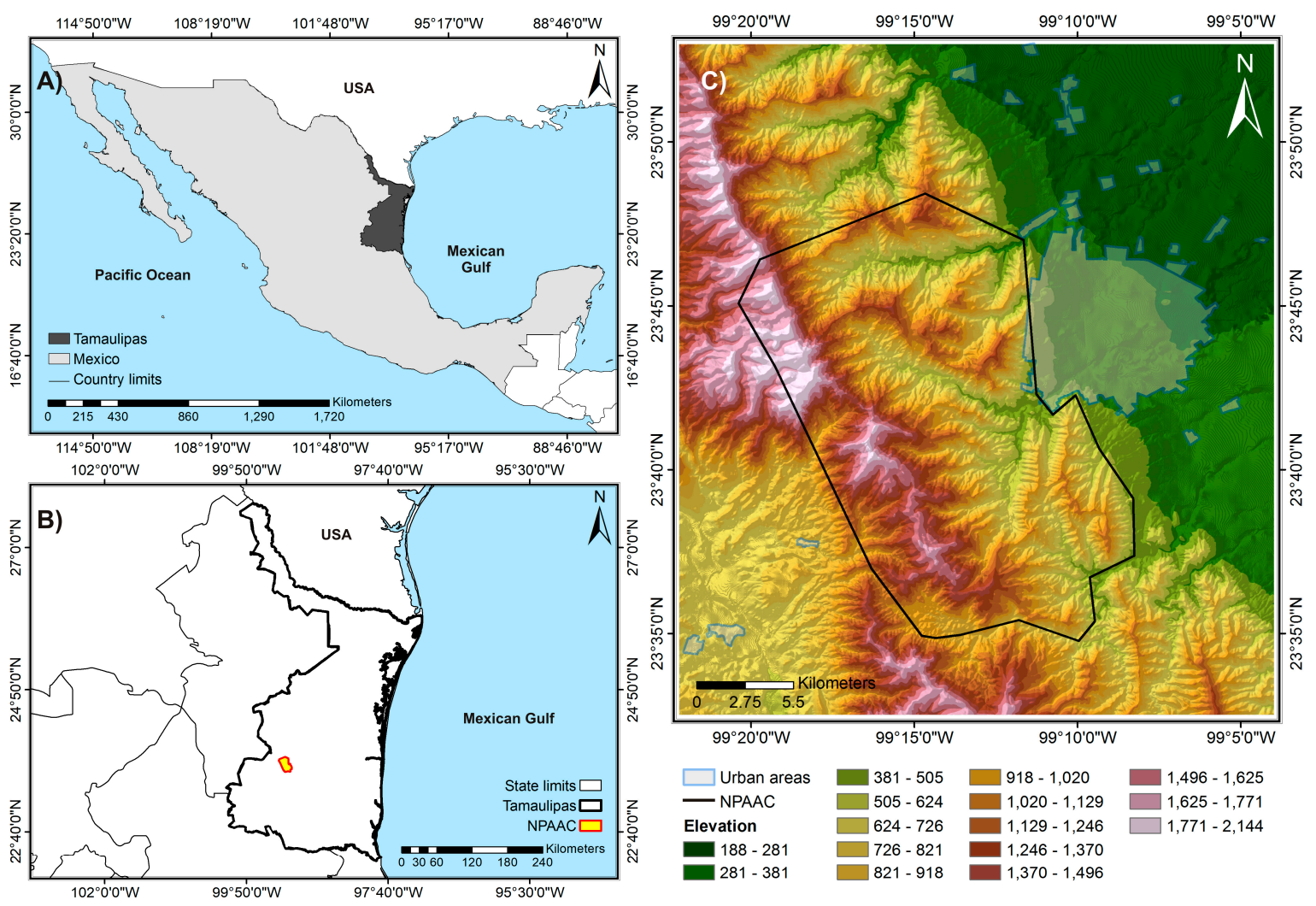

Figure 1. Location of the Natural Protected Area Altas Cumbres (NPAAC). (A) Location of Tamaulipas in Northeastern Mexico; (B) Geographical position of the NPAAC in the state of Tamaulipas; (C) NPAAC elevation range and its adjacent urban areas.

The study area encompasses an area of $303.2785 \mathrm{~km}^{2}$ in the upper basin of the San Marcos River, within the physiographic province of the Sierra Madre Oriental. Its elevation gradient is between 450-2180 m [42-44]. The average monthly temperature varies between $16.4{ }^{\circ} \mathrm{C}$ in January to $29.2^{\circ} \mathrm{C}$ in July, while the annual average temperature is between 16.5 to $22.7^{\circ} \mathrm{C}$ [43]. Climate, based on the modified classification of Köppen [45], corresponds to three different types that characterize Tamaulipas: sub-humid and semi-warm with summer rainfall, semi-dry and semi-warm, and temperate sub-humid with summer rainfall [42].

The NPAAC is considered of great biological, economic and social importance in northeastern Mexico, due to the presence of the main hydrological basins of the region, several geological and paleontological formations, as well as some archaeological sites of considerable relevance [42-44]. This NPA is home to exceptional faunistic diversity, since it represents one of the 15 panbiogeographic 
nodes of Mexico, where three biogeographic provinces interact [38]. Also, its geographical position favors the presence of 13 vegetation types including pine forest, pine-oak forest, oak forest, cloud forest, riparian forest, palm vegetation, submontane scrub, xerophile rosetophilous scrub, Tamaulipan thornscrub, chaparral (sclerophyllous scrub), and low tropical semideciduous forest [44,46]. In addition, 1164 species of vascular plants are reported, which currently places the NPAAC as the most important floristic area of Tamaulipas, since a reduced area is home to $5 \%$ of the flora of Mexico [44].

However, recent assessments suggest that ecological integrity in the NPAAC may be at risk due to several natural and anthropogenic causes, as well as management issues [42]. The frequency of fires along with the accelerated population growth in the last 10 years, are among the main disturbance factors in the area. The increase of human settlements at the skirts of the mountain range in the limits of the NPAAC is the main factor that causes loss of native scrub vegetation and low tropical semi deciduous forest. These are among the most diverse plant communities in the study area. Likewise, natural meteorological risk factors such as prolonged droughts, combined with anthropogenic activities such as clandestine and selective logging of timber and non-timber forest species, mining activity, clearing, and cattle grazing [42,44], are threatening factors for biodiversity in the NPAAC.

\subsection{Data Acquisition and Preprocessing}

The analysis was performed using Landsat satellite images of five temporal stages. We used previously corrected and orthorectified images of 1973, 1986, 2000, and 2005, available through the Global Land Survey project [47], from the Global Land Cover Facility website [48], as well as a 2015 image obtained from the USGS Global Visualization Viewer online site [49]; this last scene had also been previously corrected, given that it is 1LT product (level-one terrain-corrected (L1T) Landsat data) [50]. Whenever possible, images of the same season were selected to minimize the effect of seasonality on vegetation. Details for each scene are presented in Table 1.

Table 1. Details of the Landsat images and some parameters used for the analysis of land use-cover change in the Natural Protected Area Altas Cumbres and adjacent areas. Tamaulipas, Mexico.

\begin{tabular}{cccccccc}
\hline Year & Satellite & Sensor & $\begin{array}{c}\text { Coordinate } \\
\text { of Location } \\
\text { (Path/Row) }\end{array}$ & Date of Image & $\begin{array}{c}\text { Spatial } \\
\text { Resolution }\end{array}$ & $\begin{array}{c}\text { Bands for } \\
\text { False Color } \\
\text { Image }\end{array}$ & $\begin{array}{c}\text { Bands for Spectral } \\
\text { Signature } \\
\text { Extraction }\end{array}$ \\
\hline 1973 & Landsat 1 & MSS & $028 / 044$ & 27 May 1973 & $60 \mathrm{~m}$ & $1,2,3$ & $1,2,3,4$, NDVI \\
1986 & Landsat 5 & TM & $027 / 044$ & 14 March 1986 & $30 \mathrm{~m}$ & $2,3,4$ & $1,2,3,4,5$, NDVI \\
2000 & Landsat 7 & ETM+ & $027 / 044$ & 9 December 2000 & $30 \mathrm{~m}$ & $2,3,4$ & $1,2,3,4,5$, NDVI \\
2005 & Landsat 7 & ETM+ & $027 / 044$ & 5 November 2005 & $30 \mathrm{~m}$ & $3,4,5$ & $1,2,3,4,5$, NDVI \\
2015 & Landsat 8 & OLI-TIRS & $027 / 044$ & 27 December 2015 & $30 \mathrm{~m}$ & $3,4,5$ & $2,3,4,5,6$, NDVI \\
\hline
\end{tabular}

The area of interest included the polygon of the NPAAC, as well as the adjacent areas around it, aiming to quantify the LULCC in the nearest urban areas, because of their importance and influence on the interior of NPAs $[11,31,36,37]$. The area was delimited and extracted from each of the images of interest (bands) (Table 1) for each of the five Landsat scenes, using the program ENVI Version 5.0 [51]. All images were cropped and extracted with the same geographical extent. The cell size of the 1973 image was modified for the sake of uniformity with the other images, from 60 to $30 \mathrm{~m}$.

\subsection{Classification}

The images were imported into the IDRISI Selva 17.0 program, then a classification was performed by segmentation of the image in conjunction with the maximum likelihood algorithm (MAXLIKE) [52]. The segmentation was carried out with bands 1, 2, 3, 4 and the Normalized Difference Vegetation Index (NDVI) for the scene of 1973; bands 1, 2, 3, 4, 5 and NDVI for the scenes of 1986, 2000 and 2005; and bands 2, 3, 4, 5, 6 and NDVI for the 2015 scene (Table 1). As parameters of the segmentation, a zero-similarity tolerance was defined between the fragments, so that the initial segments generated by the segmentation remained as individual and as homogeneous as possible [52]. Subsequently, 
30 segments were selected manually as training sites for each of the seven chosen land use-cover categories (LULC). A false color image for each stage, in conjunction with several LULC data layers available through the National Institute of Statistics and Geography (INEGI, the official Mexican agency responsible for cartography development) were used as the basis for choosing training camps for the scenes of 1973 [53], 1986 [54], 2000 [55], 2005 [56] and 2015 [57]; additionally, current satellite imagery from Google Earth and previous visits to the study area were used as ancillary elements. In total, 210 segments were manually selected for each temporal scene.

The LULC categories were defined based on the most recent descriptions of vegetation types for the study area [44,46]; with the aim of avoiding confusion in the classification, the different types of cover, land use and vegetation in the study area were grouped into only seven LULC categories, given the similarity in species composition and structure among different vegetation types. These categories were as follows: (A) Urban and bare soil areas, (B) Temperate forests, (C) Tropical vegetation, (D) Scrub vegetation, (E) Sparse herbaceous vegetation, (F) Dense herbaceous vegetation, and (G) Sparse woody vegetation. Vegetation types, land use, and vegetal cover included in each LULC category are presented in Table 2.

Table 2. Land use-cover (LULC) categories, Natural Protected Area Altas Cumbres and adjacent areas. Tamaulipas, Mexico.

\begin{tabular}{ll}
\hline \multicolumn{1}{c}{ Category } & \multicolumn{1}{c}{ Description } \\
\hline A. Urban and bare soil areas & $\begin{array}{l}\text { Urban areas; semi-urban areas; areas with scarce vegetation; bare } \\
\text { soil areas; rocks; dry rivers without vegetation. }\end{array}$ \\
\hline B. Temperate forests & $\begin{array}{l}\text { Dense vegetation of oak forests, pine forests, oak-pine forests, } \\
\text { pine-oak forests, and cloud forest. }\end{array}$ \\
\hline C. Tropical vegetation & $\begin{array}{l}\text { Dense vegetation of low tropical semideciduous forest, low } \\
\text { thorny forest, and riparian vegetation. }\end{array}$ \\
\hline D. Scrub vegetation & $\begin{array}{l}\text { Dense vegetation of submontane scrub, Tamaulipan thornscrub, } \\
\text { and chaparral; vegetation on mountain slopes/hills. }\end{array}$ \\
\hline E. Sparse herbaceous vegetation & $\begin{array}{l}\text { Sparse, low herbaceous secondary vegetation; grassland; grass } \\
\text { cover at ground level; crops without dense vegetation; } \\
\text { abandoned crops. }\end{array}$ \\
\hline F. Dense herbaceous vegetation & $\begin{array}{l}\text { Very dense, low-medium herbaceous secondary vegetation; } \\
\text { dense grasslands; dense crop vegetation; active agriculture areas. }\end{array}$ \\
\hline G. Sparse woody vegetation & $\begin{array}{l}\text { Sparse secondary shrub vegetation; xerophile scrub; } \\
\text { rosetophilous scrub; huizachal. }\end{array}$ \\
\hline
\end{tabular}

The spectral signature for each category was then generated based on the chosen training fields and corresponding bands for each image (Table 1). Finally, the image was classified by MAXLIKE, using the spectral signatures previously generated, and using the option of equal previous probabilities for each signature. The five resulting images classified by MAXLIKE were analyzed to obtain the values and percentages of extension in $\mathrm{km}^{2}$ for each LULC category; these values were obtained separately for the interior of the NPAAC as well as for the adjacent areas. The procedures were performed in IDRISI Selva 17.0.

\subsection{Validation of Classification}

To determine the validity of classification, 300 ground truth points were used for each of the five previously classified images, which were generated through a randomized stratified procedure in IDRISI Selva 17.0. By using a stratified random scheme, the software distributed the 300 random points proportionally between the seven categories, according to the size of the area for each one. Then, each of these point locations required being assigned to a true land cover value [52]. For the images of 1973, 1986, 2000, and 2005, we used the historical land use and cover cartography of INEGI 
(which is available for each of the four temporal periods) [53-56], as a real basis map for categorize each of the random points and assign each one a correct category value in IDRIS Selva 17.0. We also used false color Landsat images as ancillary elements for visual aid in the delimitation of the correct categories. A similar approach was followed for the 2015 image: 300 random points were defined, which were categorized using current satellite imagery from Google Earth, modern INEGI cartography [57] and, when possible, direct field validation, as some of the random points generated were sometimes located on inaccessible areas. The categorized ground truth points were contrasted with the previously classified images through an error matrix and the Kappa index of agreement [58].

\subsection{Detection of Changes by Subsequent Classification}

Post-classification analysis allows us to know the quantity, location and nature of LULCC by comparing two classified maps; in such a way, a "from-to" matrix of changes was generated [4] using the Cross tabulation module of IDRISI Jungle 17.0. The five images classified by MAXLIKE were pairwise compared to detect patterns of change between 1973-1986, 1986-2000, 2000-2005 and 2005-2015. The analysis extended from 1973 to 2015 in order to summarize the process of the LULCC over the 42 -year period. The units in the change matrix were obtained as $\mathrm{km}^{2}$ and percentages, and were calculated separately for the interior and exterior of the NPA.

\subsection{Succession Analysis}

We determined the history of vegetation changes over 42 years only for the main three land cover categories in our study: Temperate forests, Tropical vegetation, and Scrub vegetation. For this purpose, we use the Cross tabulation module and the previous five images (classified by MAXLIKE). The Cross tabulation module in IDRISI Selva 17.0 allows for a maximum of 256 combinations; thus we were forced to separate this analysis into three main steps.

\subsubsection{Step 1. Succession Process in Temperate Forests and Tropical Vegetation}

To determine the history of vegetation changes over 42 years, we use the Cross tabulation module and the previous five LULC images (classified by MAXLIKE). First, for each image, it was necessary to reclassify the seven LULC categories (categories A to G, Table 2) into three simplified categories, assigning new values (Figure 2). Simplified Category 0 was assigned a value of " 0 ", and included the Urban or bare soil areas, Scrub vegetation, Sparse and Dense herbaceous vegetation, and Sparse woody vegetation (see Table 2, categories A, D, E, F, G), since all these are categories of disturbance and vegetation in initial states of succession. Simplified Category 1 was assigned a value of " 1 ", and included only Temperate forests (Table 2, category B). And Simplified Category 2 was assigned a value of " 2 ", and included only Tropical vegetation (Table 2 , category C). It was assumed that the Scrub vegetation represented a category of disturbance, or a successional stage prior to the presence of Temperate forests and Tropical vegetation [59]. We treated each of the five images with the same procedure; hereafter, we name these new reclassified images "Simplified Images" (Figure 2).

After reclassification of the five LULC images into five new Simplified images, we conducted the succession analysis using the Cross tabulation module (Figure 2). First, the Simplified Image of 1973 was compared against the Simplified Image of 1986 by cross-tabulation to determine the changes that occurred in that time interval. In this way, a new file was generated in which nine categories were shown; we call this hereafter "Transitional Image". This was contrasted with the Simplified Image of 2000, resulting in a new Transitional Image with 27 categories. The process was repeated, comparing this file (changes 1975-1986-2000) vs. the Simplified Image of 2005, resulting in 81 categories. Finally, the Transitional Image that included the changes during the first four stages was contrasted with the Simplified Image of 2015, resulting in a final Transitional Image with 243 categories (Figure 2). These 243 categories indicated the possible combinations of persistence and transition of vegetation that may have occurred over a period of 42 years (from 1973 to 2015). These categories were not evaluated or 
quantified as such, representing only transition and persistence of disturbed and undisturbed areas, with values of "0" (Simplified Category 0), "1" (Simplified Category 1), or "2" (Simplified Category 2).

a)

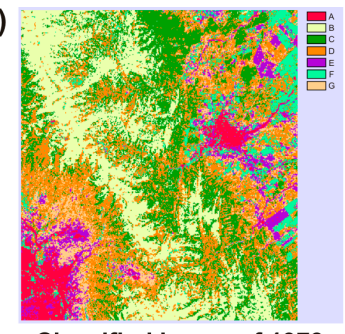

Classified image of 1973 showing 7 LULC categories

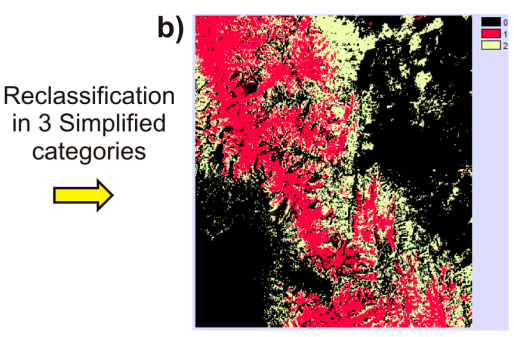

Simplified image of 1973

c) All LULC images are reclassified into Simplified images
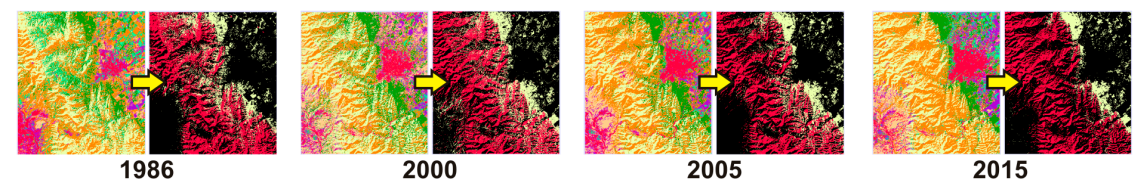

d) Linked Cross Tabulation (CrossTab) is conducted using Simplified and resulting Transitional images. Each green arrow indicates the resulting image from the prior cross tabulation (blue arrows)

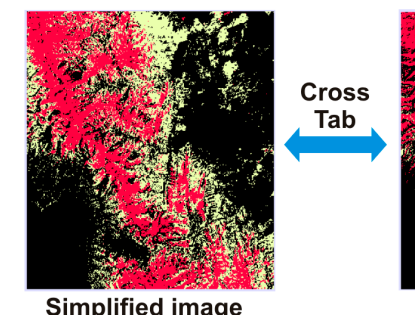

Simplified image of 1973

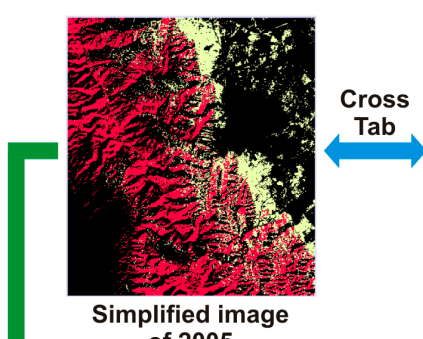

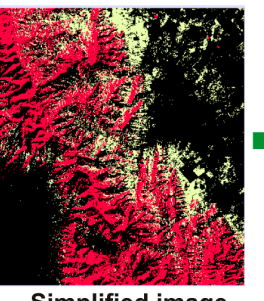

Simplified image of 1986

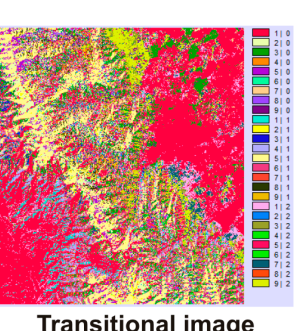

Transitional image 1973-1986-2000

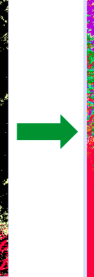
Transitional image
$1973-1986$

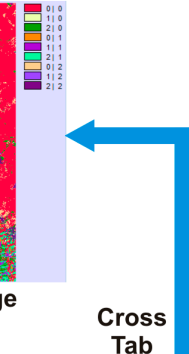

of 2005

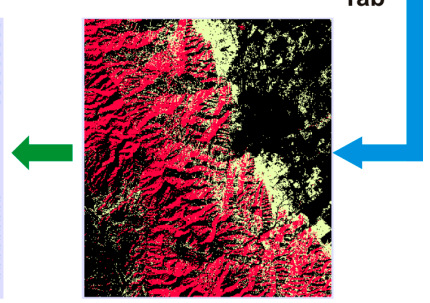

Simplified image of $\mathbf{2 0 0 0}$

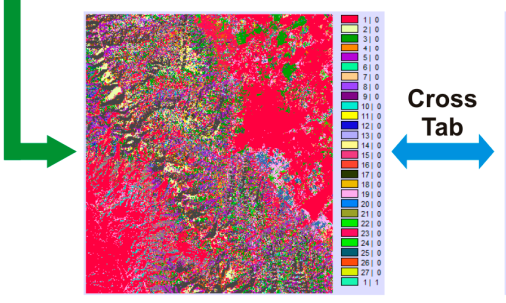

Transitional image 1973-1986-2000-2005

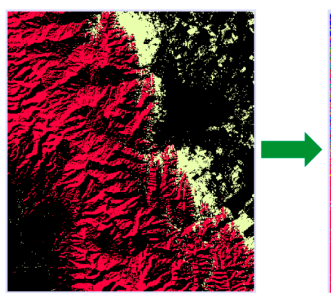

Simplified image of 2015

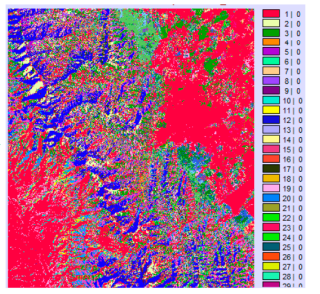

Final transitional image 1973-1986-2000-2005-2015

Figure 2. Summarized process for delimiting successional categories. (a) The first LULC image classified by MAXLIKE (b) is reclassified into three simplified categories: 0 (Disturbance Simplified Category), 1 (Temperate forests) and 2 (Tropical vegetation). (c) The other LULC images are reclassified in the same way. (d) Cross tabulation is conducted, comparing the Simplified Image of 1973 vs. that of 1986, resulting in a Transitional Image of changes for 1973-1986 with 9 categories. This is compared vs. the next Simplified Image (2000), resulting in a new Transitional Image with 27 categories. The process continues until a final Transitional Image is obtained, with 243 categories of transition from 1973-2015. See text for details. 
To make a more accurate and comprehensible analysis, the final Transitional Image was reclassified to show only 11 categories; we call these new categories hereafter "Succession Categories". This categorization was made on the basis of transition from a disturbance category (Simplified Category 0, value of " 0 ") to original-native vegetation, either Temperate forest (Simplified Category 1, value of "1") or Tropical vegetation (Simplified Category 2, value of "2"), according to the following criteria.

1. Category 1: Native Temperate forests: areas with Temperate forest vegetation in 1973 that remained unchanged during the five stages until 2015.

2. Category 2: Temperate forests—42 years of succession: areas that were disturbed in 1973, but showed native vegetation in 1986 and persisted until 2015.

3. Category 3: Temperate forests-29 years of succession: areas that were disturbed in 1986, but showed native vegetation in 2000 and persisted up to 2015.

4. Category 4: Temperate forests-15 years of succession: areas that were disturbed in 2000, but showed native vegetation in 2005, and persisted until 2015.

5. Category 5: Temperate forests-10 years of succession: areas that were disturbed in 2005, but showed native vegetation in 2015.

6. Category 6: Native Tropical vegetation: areas with Tropical vegetation in 1973 that remained unchanged during the five stages until 2015.

7. Category 7: Tropical vegetation-42 years of succession: areas that were disturbed in 1973, but showed native vegetation in 1986 and persisted until 2015.

8. Category 8: Tropical vegetation-29 years of succession: areas that were disturbed in 1986, but showed native vegetation in 2000 and persisted up to 2015.

9. Category 9: Tropical vegetation-15 years of succession: areas that were disturbed in 2000, but showed native vegetation in 2005, and persisted until 2015.

10. Category 10: Tropical vegetation-10 years of succession: areas that were disturbed in 2005, but showed native vegetation in 2015.

11. Category 11: Temperate forests/tropical vegetation without linear succession: areas with either Temperate Forests or Tropical Vegetation in 2015, which exhibited different and varied recovery and transition processes, including change from one type of cover to another; that is, we assumed that Tropical vegetation does not precede the Temperate forest during the succession, and vice versa.

Through this reclassification, we obtained a new image with 11 Succession Categories, hereafter named "Successional Image of Temperate forests-Tropical vegetation". The transition processes are summarized in Table 3.

\subsubsection{Step 2. Succession Process in the Scrub Vegetation}

As stated before, the Cross Tabulation module in IDRISI allows only for a maximum of 256 combinations. In the Step 1, we calculated the successional patterns and transitions between three Simplified Categories (Disturbance, Temperate forests and Tropical vegetation) during the five temporal stages in our study, which totalizes 243 combinations $(3 \times 3 \times 3 \times 3 \times 3=243)$. A transition analysis during these five years, but using four categories, was impossible, since the number of combinations exceed the limit of the software $(4 \times 4 \times 4 \times 4 \times 4=1024)$. Therefore, the delimitation of the successional time for Scrub vegetation was conducted separately, following almost exactly the same method (Figure 2), but with some minor differences in the procedure.

First, as done before, each of the five LULC images (each with seven categories) was reclassified to show three Simplified Categories. Simplified Category 0 was assigned a value of " 0 ", but only included the Urban or bare soil areas, Sparse and Dense herbaceous vegetation, and Sparse woody vegetation (see Table 2, categories A, E, F, G), which are considered categories of disturbance and vegetation in initial states of succession for the Scrub vegetation. Simplified Category 3 was assigned a 
value of "3", and included only Scrub vegetation (Table 2, category D). Finally, we add a Simplified Category-99 in which both Temperate forests (Table 2, Category B) and Tropical vegetation (Table 2, Category C) were included; no further analysis was conducted on this Simplified Category, because all changes and transitions were already calculated in Step 1. It was added only with the objective of differentiating the remaining areas from the Simplified Category 0 and Simplified Category 3, and so it was assigned the non-important "-99" value.

Table 3. Transition processes for the succession analysis. $0=$ Disturbance (Simplified Category 0); $1=$ Temperate forests (Simplified Category 1); 2 = Tropical vegetation (Simplified Category 2); 3 = Scrub vegetation (Simplified Category 3$)$. Hyphen indicates that any value $(0,1,2$, or 3$)$ was considered for that year (see text for details).

\begin{tabular}{lccccc}
\hline \multicolumn{1}{c}{ Succession Categories } & $\mathbf{1 9 7 3}$ & $\mathbf{1 9 8 6}$ & $\mathbf{2 0 0 0}$ & $\mathbf{2 0 0 5}$ & $\mathbf{2 0 1 5}$ \\
\hline 1. Native Temperate forests & 1 & 1 & 1 & 1 & 1 \\
2. Temperate forests-42 years of succession & 0 & 1 & 1 & 1 & 1 \\
3. Temperate forests-29 years of succession & 0 & 0 & 1 & 1 & 1 \\
4. Temperate forests-15 years of succession & 0 & 0 & 0 & 1 & 1 \\
5. Temperate forests-10 years of succession & 0 & 0 & 0 & 0 & 1 \\
6. Native Tropical vegetation & 2 & 2 & 2 & 2 & 2 \\
7. Tropical vegetation-42 years of succession & 0 & 2 & 2 & 2 & 2 \\
8. Tropical vegetation-29 years of succession & 0 & 0 & 2 & 2 & 2 \\
9. Tropical vegetation-15 years of succession & 0 & 0 & 0 & 2 & 2 \\
10. Tropical vegetation-10 years of succession & 0 & 0 & 0 & 0 & 2 \\
11. Temperate forests/tropical vegetation without & - & - & - & - & 1 or 2 \\
linear succession & 3 & 3 & 3 & 3 & 3 \\
12. Native Scrub vegetation & 0 & 3 & 3 & 3 & 3 \\
13. Scrub vegetation-42 years of succession & 0 & 0 & 3 & 3 & 3 \\
14. Scrub vegetation-29 years of succession & 0 & 0 & 0 & 3 & 3 \\
15. Scrub vegetation-15 years of succession & 0 & 0 & 0 & 0 & 3 \\
16. Scrub vegetation-10 years of succession & - & - & - & - & 3 \\
17. Scrub vegetation without linear succession & - & - & - & - & 0 \\
18. Modified areas & 0 & 0 & 0 & 0 & 0 \\
19. Persistence of disturbance & & & &
\end{tabular}

The linked cross-tabulation process was carried out as described previously, using the five Simplified Images to obtain a final Transitional Image (Figure 2). The 243 categories in the final Transitional Image were then reclassified, according to the following criteria:

12. Category 12: Native Scrub vegetation: areas with Scrub vegetation in 1973 that remained unchanged during the five stages until 2015.

13. Category 13: Scrub vegetation-42 years of succession: areas that were disturbed in 1973, but showed native vegetation in 1986 and persisted until 2015.

14. Category 14: Scrub vegetation-29 years of succession: areas that were disturbed in 1986, but showed native vegetation in 2000 and persisted up to 2015.

15. Category 15: Scrub vegetation-15 years of succession: areas that were disturbed in 2000, but showed native vegetation in 2005, and persisted until 2015.

16. Category 16: Scrub vegetation-10 years of succession: areas that were disturbed in 2005, but showed native vegetation in 2015.

17. Category 17: Scrub vegetation without linear succession: areas of Scrub vegetation in 2015, which exhibited different and varied recovery and transition processes, including change from one type of cover to another.

18. Category 18: Modified areas: these included all categories (out of 240 in the final Transitional image) where the disturbance was observed in 2015, without taking into account the previous changes or transition process. 
19. Category 19: Persistence of disturbance: represent the categories with persistence of disturbance since 1973 until 2015.

Through this reclassification, we obtained a new image with eight Succession categories, hereafter named "Successional Image of Scrub vegetation". The transition processes are summarized in Table 3.

\subsubsection{Step 3. Map of Succession for the Main Three Land Cover Categories}

The area values $\left(\mathrm{km}^{2}\right)$ and percentages of coverage for the first 11 Succession categories (Categories 1 to 11) were obtained from the Successional Image of Temperate forests-Tropical vegetation. Values for the remaining eight Succession categories (12 to 19) were calculated from the Successional Image of the Scrub vegetation. In both cases, values were measured independently for the interior of the NPAAC and for adjacent areas using IDRISI Selva 17.0. Finally, the Successional Image of the Scrub vegetation was displayed over the Successional Image of the Temperate Forests-Tropical Vegetation to generate a single map of succession using the program ArcGIS 10.9 [60].

\section{Results}

\subsection{Validation and Land Use-Cover during the Period 1973-2015}

The overall accuracy percentages for the five LULC maps increased from $90.33 \%$ for the 1973 image to $96 \%$ for the 2015 image. Similarly, the Kappa coefficient increased from 88\% in 1973 to $94.93 \%$ in 2015 (Tables 4-8). Furthermore, producer and user accuracy percentages were obtained for each stage and category of LULC.

Table 4. Error matrix for land use-cover, 1973. Natural Protected Area Altas Cumbres. Victoria, Tamaulipas, Mexico.

\begin{tabular}{lccccccccc}
\hline & A & B & C & D & E & F & G & Row Total & User's acc. (\%) \\
\hline A-Urban/bare soil & 16 & 0 & 0 & 0 & 1 & 0 & 0 & 17 \\
B-Temperate forests & 0 & 72 & 2 & 3 & 0 & 0 & 0 & 77 & 94.12 \\
C-Tropical vegetation & 0 & 0 & 51 & 2 & 1 & 0 & 2 & 56 & 93.51 \\
D-Scrub vegetation & 0 & 0 & 2 & 72 & 1 & 2 & 2 & 79 & 91.07 \\
E-Sparse herbaceous vegetation & 1 & 0 & 0 & 2 & 23 & 0 & 0 & 26 & 91.14 \\
F-Dense herbaceous vegetation & 1 & 0 & 1 & 2 & 0 & 20 & 0 & 24 & 88.46 \\
G-Woody sparse vegetation & 0 & 0 & 1 & 2 & 1 & 0 & 17 & 21 & 83.33 \\
Column total & 18 & 72 & 57 & 83 & 27 & 22 & 21 & 300 \\
Producer's acc. (\%) & 88.89 & 100 & 89.47 & 86.75 & 85.19 & 90.91 & 80.95 & & \\
Overall acc. (\%) & 90.33 & & & & & & & & \\
Overall Kappa & 0.8804 & & & & & & & \\
\hline
\end{tabular}

Table 5. Error matrix for land use-cover, 1986. Natural Protected Area Altas Cumbres. Victoria, Tamaulipas, Mexico.

\begin{tabular}{lccccccccc}
\hline & A & B & C & D & E & F & G & Row Total & User's acc. (\%) \\
\hline A-Urban/bare soil & 17 & 0 & 0 & 0 & 0 & 1 & 0 & 18 & 94.44 \\
B-Temperate forests & 0 & 60 & 2 & 1 & 0 & 0 & 0 & 63 & 95.24 \\
C-Tropical vegetation & 0 & 2 & 51 & 3 & 0 & 0 & 0 & 56 & 91.07 \\
D-Scrub vegetation & 0 & 0 & 1 & 100 & 0 & 0 & 4 & 105 & 95.24 \\
E-Sparse herbaceous vegetation & 0 & 0 & 0 & 1 & 16 & 0 & 1 & 18 & 88.89 \\
F-Dense herbaceous vegetation & 0 & 0 & 1 & 2 & 2 & 19 & 0 & 24 & 16 \\
G-Woody sparse vegetation & 0 & 0 & 0 & 2 & 0 & 0 & 14 & 300 \\
Column total & 17 & 62 & 55 & 109 & 18 & 20 & 19 & \\
Producer's acc. (\%) & 100 & 96.77 & 92.73 & 91.74 & 88.89 & 95 & 73.68 & \\
Overall acc. (\%) & 92.33 & & & & & & & & \\
Overall Kappa & 0.9016 & & & & & & & \\
\hline
\end{tabular}


Table 6. Error matrix for land use-cover, 2000. Natural Protected Area Altas Cumbres. Victoria, Tamaulipas, Mexico.

\begin{tabular}{lccccccccc}
\hline & A & B & C & D & E & F & G & Row Total & User's acc. (\%) \\
\hline A-Urban/bare soil & 17 & 0 & 0 & 0 & 1 & 0 & 0 & 18 & 94.44 \\
B-Temperate forests & 0 & 79 & 2 & 2 & 0 & 0 & 1 & 84 & 94.05 \\
C-Tropical vegetation & 0 & 1 & 47 & 2 & 0 & 0 & 1 & 51 & 92.16 \\
D-Scrub vegetation & 0 & 3 & 2 & 76 & 0 & 0 & 0 & 81 & 93.83 \\
E-Sparse herbaceous vegetation & 0 & 0 & 0 & 1 & 17 & 0 & 1 & 19 & 89.47 \\
F-Dense herbaceous vegetation & 0 & 0 & 0 & 0 & 0 & 5 & 0 & 5 & 100 \\
G-Woody sparse vegetation & 0 & 0 & 2 & 1 & 2 & 0 & 37 & 42 & 88.1 \\
Column total & 17 & 83 & 53 & 82 & 20 & 5 & 40 & 300 & \\
Producer's acc. (\%) & 100 & 95.18 & 88.68 & 92.68 & 85 & 100 & 92.5 & & \\
Overall acc. (\%) & 92.67 & & & & & & & & \\
Overall Kappa & 0.9074 & & & & & & & & \\
\hline
\end{tabular}

Table 7. Error matrix for land use-cover, 2005. Natural Protected Area Altas Cumbres. Victoria, Tamaulipas, Mexico.

\begin{tabular}{lccccccccc}
\hline & A & B & C & D & E & F & G & Row Total & User's acc. (\%) \\
\hline A-Urban/bare soil & 25 & 0 & 0 & 0 & 0 & 1 & 0 & 26 \\
B-Temperate forests & 0 & 83 & 2 & 0 & 0 & 0 & 0 & 85 \\
C-Tropical vegetation & 0 & 0 & 30 & 3 & 0 & 0 & 0 & 33 & 96.15 \\
D-Scrub vegetation & 0 & 0 & 3 & 95 & 0 & 0 & 0 & 98 & 90.65 \\
E-Sparse herbaceous vegetation & 0 & 0 & 0 & 2 & 19 & 0 & 1 & 22 & 96.94 \\
F-Dense herbaceous vegetation & 0 & 0 & 0 & 0 & 0 & 8 & 0 & 86.36 \\
G-Woody sparse vegetation & 1 & 1 & 0 & 1 & 0 & 0 & 25 & 28 & 300 \\
Column total & 26 & 84 & 35 & 101 & 19 & 9 & 26 & 39.29 \\
Producer's acc. (\%) & 96.15 & 98.81 & 85.71 & 94.06 & 100 & 88.89 & 96.15 & & \\
Overall acc. (\%) & 95 & & & & & & & & \\
Overall Kappa & 0.9356 & & & & & & & \\
\hline
\end{tabular}

Table 8. Error matrix for land use-cover, 2015. Natural Protected Area Altas Cumbres. Victoria, Tamaulipas, Mexico.

\begin{tabular}{lccccccccc}
\hline & A & B & C & D & E & F & G & Row Total & User's acc. (\%) \\
\hline A-Urban/bare soil & 21 & 0 & 0 & 1 & 0 & 0 & 0 & 22 & 95.45 \\
B-Temperate forests & 0 & 75 & 0 & 1 & 0 & 0 & 1 & 77 & 97.4 \\
C-Tropical vegetation & 0 & 0 & 25 & 0 & 0 & 0 & 0 & 25 & 100 \\
D-Scrub vegetation & 0 & 0 & 3 & 97 & 0 & 0 & 0 & 100 & 97 \\
E-Sparse herbaceous vegetation & 0 & 0 & 0 & 0 & 27 & 1 & 2 & 30 & 90 \\
F-Dense herbaceous vegetation & 0 & 0 & 0 & 1 & 0 & 22 & 0 & 23 & 95.65 \\
G-Woody sparse vegetation & 0 & 0 & 0 & 1 & 1 & 0 & 21 & 23 & 91.3 \\
Column total & 21 & 75 & 28 & 101 & 28 & 23 & 24 & 300 & \\
Producer's acc. (\%) & 100 & 100 & 89.29 & 96.04 & 96.43 & 95.65 & 87.5 & & \\
Overall acc. (\%) & 96 & & & & & & & & \\
Overall Kappa & 0.9493 & & & & & & & & \\
\hline
\end{tabular}

In the first stage evaluated, 1973, the dominant vegetation category, with the greatest extension within the NPAAC polygon, was Temperate forests, $120.4506 \mathrm{~km}^{2}$ representing $38.15 \%$ of the total cover. Other important categories were Tropical vegetation (29.06\%) and Scrub vegetation $(27.24 \%)$. The proportion of Dense herbaceous vegetation and Sparse woody vegetation was close to $8 \mathrm{~km}^{2}$ considering both categories (2.44\% and $2.26 \%$, respectively). The lowest cover values were for Sparse herbaceous vegetation $\left(1.7559 \mathrm{~km}^{2}, 0.56 \%\right)$ and Urban and bare soil areas $\left(0.8865 \mathrm{~km}^{2}, 28 \%\right)$ (Figure 3 , Appendix A-Figure A1). In 1986, the Scrub category increased to $117.6624 \mathrm{~km}^{2}(37.27 \%$ of total coverage); in contrast, the area occupied by Temperate forests declined by almost $20 \mathrm{~km}^{2}$, while Tropical vegetation reduced its area over $30 \mathrm{~km}^{2}$. Sparse herbaceous and woody vegetation cover decreased. However, Dense herbaceous vegetation expanded to $26.6508 \mathrm{~km}^{2}(8.44 \%)$ (Figure 3, Appendix A-Figure A2). 


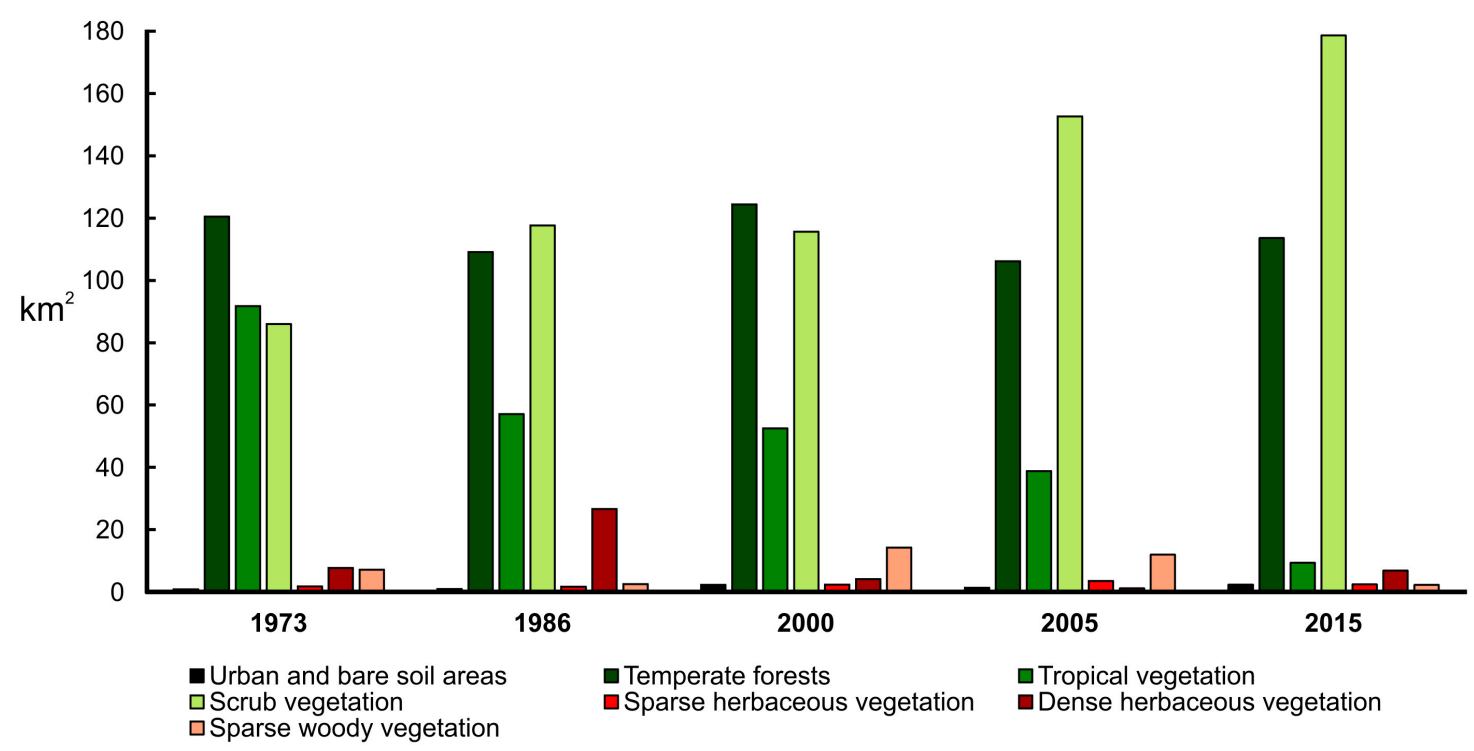

Figure 3. Occupied area $\left(\mathrm{km}^{2}\right)$ for each land use-cover category over the study period, Natural Protected Area Altas Cumbres polygon. Victoria, Tamaulipas, Mexico.

In 2000, Temperate forests slightly recovered in relation to Scrub vegetation $(39.41 \%$ vs. $36.63 \%$ of the total area, respectively), although Tropical vegetation coverage fell to $52.515 \mathrm{~km}^{2}(16.63 \%)$. The proportion of Dense herbaceous vegetation decreased in relation to Sparse woody vegetation that showed an increment (14.2686 km², 4.52\%) (Figure 3, Appendix A-Figure A3).

Important changes have been observed since 2005, as the area occupied by Temperate forests and Tropical vegetation has diminished drastically, occupying $33.64 \%$ and $12.28 \%$ of the total area, respectively; on the contrary, Scrub vegetation cover augmented to $152.6436 \mathrm{~km}^{2}$ and accounted for $48.35 \%$ of total coverage in 2005 (Figure 3, Appendix A-Figure A4). The Sparse woody vegetation occupied $11.9592 \mathrm{~km}^{2}(3.79 \%)$. A similar trend continued in 2015, with a drastic reduction in Tropical vegetation to only $9.4194 \mathrm{~km}^{2}$, or $2.98 \%$ of the total area, while the Scrub vegetation increased to $178.6338 \mathrm{~km}^{2}$ (56.58\% of total coverage) (Figure 3, Appendix A-Figure A5).

Regarding the adjacent areas, outside the NPAAC, the Scrub vegetation was the dominant category during almost the entire evaluated period, with a proportion of $26.41 \%$ and $33.1 \%$ of the total adjacent area; except for the year 2000, when Temperate forests represented the most extensive cover $\left(162.3312 \mathrm{~km}^{2}\right)$. However, the area occupied by the categories associated with disturbance or modified vegetation was also significant. Urban and bare soil areas increased progressively by more than $40.00 \mathrm{~km}^{2}$ from 1973 to 2015 . Similarly, although in smaller proportions, the Sparse herbaceous vegetation maintained a tendency to increase from 1973 to 2015. The coverage of Sparse woody vegetation was also representative, with a significant improvement in 2000. Dense herbaceous vegetation was extensive in 1973 and 1986, but declined in 2000, recovering again in 2005 and 2015. There was also a significant reduction in the area occupied by Tropical vegetation from 1973 to 2015, with the coverage values of this category being very similar, or even lower than, the Urban areas and other modified categories (Figure 4, Appendix A-Figures A1-A5). 


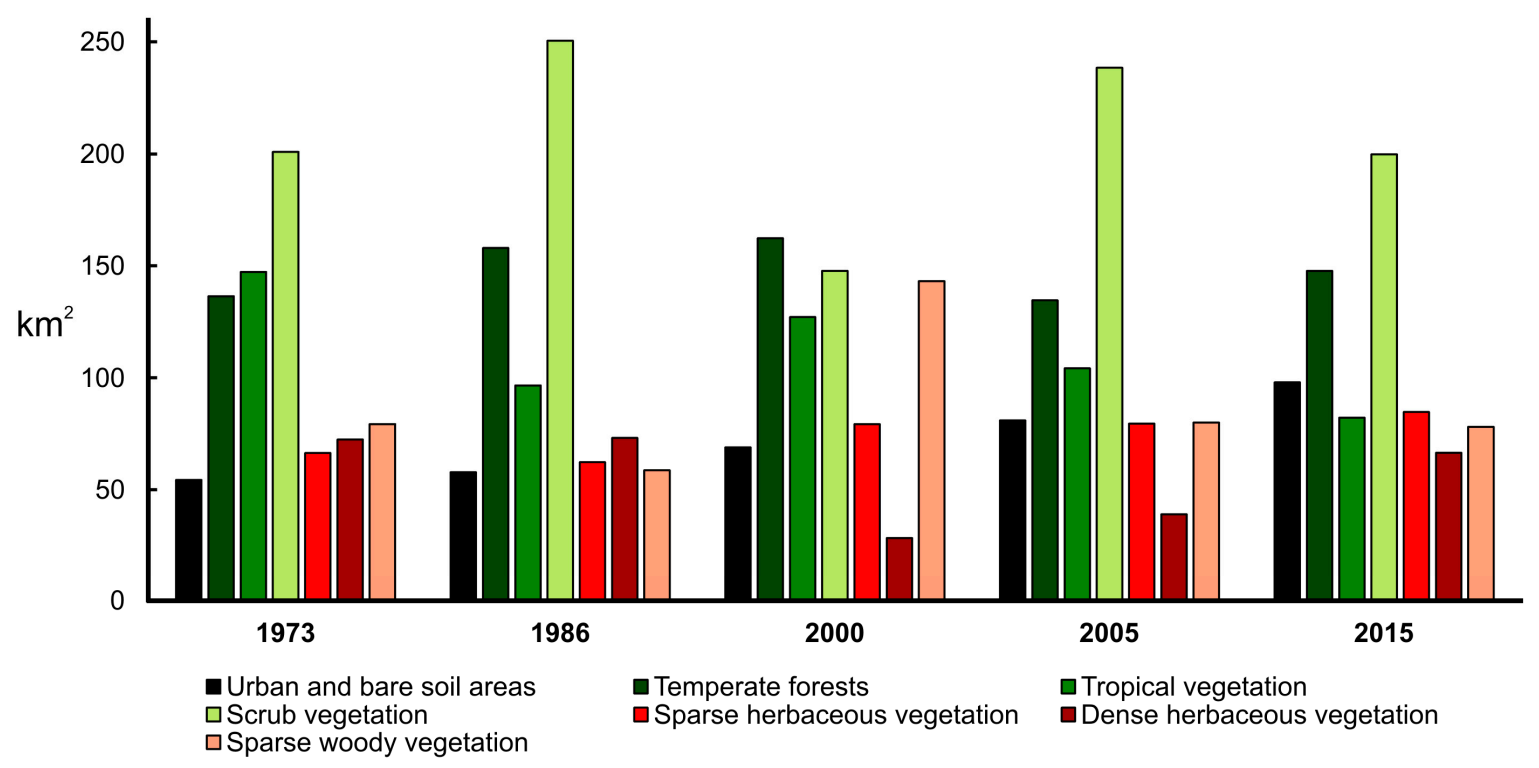

Figure 4. Occupied area $\left(\mathrm{km}^{2}\right)$ for each land use-cover category over the study period, adjacent areas of the Natural Protected Area Altas Cumbres. Victoria, Tamaulipas, Mexico.

\subsection{Land Use-Cover Changes from 1973 to 1986}

The analysis of LULCC from 1973 to 1986 within the NPAAC indicated that the greatest contribution to the change matrix was due to the persistence of $71.3196 \mathrm{~km}^{2}$ of Temperate forests that were not modified, representing $22.59 \%$ of the total area. However, $26.6202 \mathrm{~km}^{2}$ of Temperate forests and $34.8273 \mathrm{~km}^{2}$ of Tropical vegetation were modified to Scrub vegetation in $1986(8.43 \%$ and $11.03 \%$, respectively) (Table 9). In the adjacent areas, the highest transition value occurred in Tropical vegetation, with $51.1713 \mathrm{~km}^{2}$ being modified to Scrub vegetation $(6.76 \%$ of the total adjacent area). The Scrub vegetation also showed a high persistence value, with $96.3585 \mathrm{~km}^{2}$ remaining from 1973 to 1986 $(12.73 \%)$; similarly, there was a high persistence of Temperate forests outside the NPAAC $\left(91.5723 \mathrm{~km}^{2}\right.$, 12.1\%) (Table 10).

Table 9. Matrix of land use-cover changes from 1973 to 1986, in Natural Protected Area Altas Cumbres (NPAAC). Victoria, Tamaulipas, Mexico.

\begin{tabular}{|c|c|c|c|c|c|c|c|c|c|}
\hline & & & \multicolumn{7}{|c|}{1986} \\
\hline & & & $\mathbf{A}$ & B & $\mathrm{C}$ & D & E & $\mathbf{F}$ & G \\
\hline \multirow{14}{*}{1973} & \multirow{2}{*}{ A. Urban/bare soil areas } & $\mathrm{km}^{2}$ & 0.2907 & 0.0126 & 0.0036 & 0.1431 & 0.2619 & 0.1548 & 0.0198 \\
\hline & & $\%$ & 0.092 & 0.004 & 0.001 & 0.045 & 0.083 & 0.049 & 0.006 \\
\hline & \multirow{2}{*}{ B. Temperate forests } & $\mathrm{km}^{2}$ & 0.0018 & 71.3196 & 16.5816 & 26.6202 & 0.0009 & 5.697 & 0.2295 \\
\hline & & $\%$ & 0.001 & 22.592 & 5.252 & 8.432 & 0.000 & 1.805 & 0.073 \\
\hline & \multirow{2}{*}{ C. Tropical vegetation } & $\mathrm{km}^{2}$ & 0.0099 & 24.3747 & 27.099 & 34.8273 & 0.018 & 4.8933 & 0.5229 \\
\hline & & $\%$ & 0.003 & 7.721 & 8.584 & 11.032 & 0.006 & 1.550 & 0.166 \\
\hline & \multirow{2}{*}{ D. Scrub vegetation } & $\mathrm{km}^{2}$ & 0.09 & 12.4164 & 12.1275 & 47.5128 & 0.2772 & 12.465 & 1.116 \\
\hline & & $\%$ & 0.029 & 3.933 & 3.842 & 15.050 & 0.088 & 3.948 & 0.354 \\
\hline & \multirow{2}{*}{ E. Sparse herbaceous vegetation } & $\mathrm{km}^{2}$ & 0.2952 & 0.0378 & 0.009 & 0.5814 & 0.4734 & 0.2709 & 0.0882 \\
\hline & & $\%$ & 0.094 & 0.012 & 0.003 & 0.184 & 0.150 & 0.086 & 0.028 \\
\hline & \multirow{2}{*}{ F. Dense herbaceous vegetation } & $\mathrm{km}^{2}$ & 0.0846 & 0.4761 & 0.8235 & 3.3237 & 0.2592 & 2.6595 & 0.0828 \\
\hline & & $\%$ & 0.027 & 0.151 & 0.261 & 1.053 & 0.082 & 0.842 & 0.026 \\
\hline & \multirow{2}{*}{ G. Sparse woody vegetation } & $\mathrm{km}^{2}$ & 0.1539 & 0.4653 & 0.4599 & 4.6539 & 0.3987 & 0.5103 & 0.4968 \\
\hline & & $\%$ & 0.049 & 0.147 & 0.146 & 1.474 & 0.126 & 0.162 & 0.157 \\
\hline
\end{tabular}


Table 10. Matrix of land use-cover changes from 1973 to 1986, in the adjacent area of Natural Protected Area Altas Cumbres (NPAAC). Victoria, Tamaulipas, Mexico.

\begin{tabular}{llccccccc}
\hline & & \multicolumn{7}{c}{$\mathbf{1 9 8 6}$} \\
\cline { 3 - 9 } & & $\mathbf{A}$ & $\mathbf{B}$ & $\mathbf{C}$ & $\mathbf{D}$ & $\mathbf{E}$ & $\mathbf{F}$ & $\mathbf{G}$ \\
\hline \multirow{2}{*}{ A. Urban/bare soil areas } & $\mathrm{km}^{2}$ & 32.8131 & 0.0864 & 0.0693 & 1.6551 & 14.913 & 3.2769 & 1.4931 \\
& $\%$ & 4.336 & 0.011 & 0.009 & 0.219 & 1.971 & 0.433 & 0.197 \\
\hline \multirow{2}{*}{ B. Temperate forests } & $\mathrm{km}^{2}$ & 0.0495 & 91.5723 & 14.7825 & 24.669 & 0.0684 & 5.166 & 0.0657 \\
& $\%$ & 0.007 & 12.101 & 1.953 & 3.260 & 0.009 & 0.683 & 0.009 \\
\hline \multirow{2}{*}{ C. Tropical vegetation } & $\mathrm{km}^{2}$ & 0.8865 & 38.8206 & 42.624 & 51.1713 & 1.9638 & 8.4474 & 3.2949 \\
& $\%$ & 0.117 & 5.130 & 5.633 & 6.762 & 0.260 & 1.116 & 0.435 \\
\hline \multirow{2}{*}{ D. Scrub vegetation } & $\mathrm{km}^{2}$ & 4.248 & 25.0947 & 28.1817 & 96.3585 & 9.5499 & 20.8557 & 16.6464 \\
& $\%$ & 0.561 & 3.316 & 3.724 & 12.733 & 1.262 & 2.756 & 2.200 \\
\hline \multirow{2}{*}{ E. Sparse herbaceous vegetation } & $\mathrm{km}^{2}$ & 9.1431 & 0.0477 & 0.8757 & 19.8369 & 17.217 & 8.0559 & 11.1474 \\
& $\%$ & 1.208 & 0.006 & 0.116 & 2.621 & 2.275 & 1.065 & 1.473 \\
\hline \multirow{2}{*}{ F. Dense herbaceous vegetation } & $\mathrm{km}^{2}$ & 6.3162 & 0.8973 & 4.9392 & 21.8709 & 10.5453 & 19.0863 & 8.7498 \\
& $\%$ & 0.835 & 0.119 & 0.653 & 2.890 & 1.394 & 2.522 & 1.156 \\
\hline \multirow{2}{*}{ G. Sparse woody vegetation } & $\mathrm{km}^{2}$ & 4.3668 & 1.413 & 5.1066 & 34.8993 & 7.9911 & 8.1603 & 17.2431 \\
& $\%$ & 0.577 & 0.187 & 0.675 & 4.612 & 1.056 & 1.078 & 2.279 \\
\hline
\end{tabular}

\subsection{Land Use-Cover Changes from 1986 to 2000}

The largest contribution to the change matrix from 1986 to 2000 within the NPAAC was the persistence of $85.6341 \mathrm{~km}^{2}$ of Temperate forests (27.13\% of the total area) and $72.693 \mathrm{~km}^{2}$ of Scrub vegetation $(23.03 \%)$. The Tropical vegetation presented the highest percentage of transition, with $21.6036 \mathrm{~km}^{2}$ that were modified to Temperate forest $(6.84 \%)$ within the polygon of the NPAAC (Table 11). There was also a high proportion of coverage that was preserved as Temperate forests in the adjacent area $\left(120.1194 \mathrm{~km}^{2}\right.$, representing a $15.87 \%$ of the total adjacent area), as well as $76.275 \mathrm{~km}^{2}$ of Scrub vegetation (10.08\%). In addition, there was a notable conversion value from Scrub vegetation $\left(62.1486 \mathrm{~km}^{2}, 8.21 \%\right)$ to Sparse woody vegetation (Table 12$)$.

Table 11. Matrix of land use-cover changes from 1986 to 2000, in Natural Protected Area Altas Cumbres (NPAAC). Victoria, Tamaulipas, Mexico.

\begin{tabular}{llccccccc}
\hline & & & & \multicolumn{2}{c}{$\mathbf{2 0 0 0}$} \\
\cline { 3 - 9 } & & $\mathbf{A}$ & $\mathbf{B}$ & $\mathbf{C}$ & $\mathbf{D}$ & $\mathbf{E}$ & $\mathbf{F}$ & $\mathbf{G}$ \\
\hline \multirow{2}{*}{ A. Urban/bare soil areas } & $\mathrm{km}^{2}$ & 0.657 & 0.0144 & 0.0036 & 0.0324 & 0.054 & 0.0108 & 0.1539 \\
& $\%$ & 0.208 & 0.005 & 0.001 & 0.010 & 0.017 & 0.003 & 0.049 \\
\hline \multirow{2}{*}{ B. Temperate forests } & $\mathrm{km}^{2}$ & 0.0477 & 85.6341 & 9.6372 & 13.0662 & 0.018 & 0.2313 & 0.468 \\
& $\%$ & 0.015 & 27.126 & 3.053 & 4.139 & 0.006 & 0.073 & 0.148 \\
\hline \multirow{2}{*}{ C. Tropical vegetation } & $\mathrm{km}^{2}$ & 0.081 & 21.6036 & 22.1508 & 11.4138 & 0.0621 & 0.3663 & 1.4265 \\
& $\%$ & 0.026 & 6.843 & 7.017 & 3.615 & 0.020 & 0.116 & 0.452 \\
\hline \multirow{2}{*}{ D. Scrub vegetation } & $\mathrm{km}^{2}$ & 0.5922 & 14.814 & 17.5941 & 72.693 & 1.0413 & 1.6848 & 9.243 \\
& $\%$ & 0.188 & 4.693 & 5.573 & 23.027 & 0.330 & 0.534 & 2.928 \\
\hline \multirow{2}{*}{ E. Sparse herbaceous vegetation } & $\mathrm{km}^{2}$ & 0.5553 & 0.0081 & 0.0081 & 0.1656 & 0.3492 & 0.0351 & 0.5679 \\
& $\%$ & 0.176 & 0.003 & 0.003 & 0.052 & 0.111 & 0.011 & 0.180 \\
\hline \multirow{2}{*}{ F. Dense herbaceous vegetation } & $\mathrm{km}^{2}$ & 0.2826 & 2.3274 & 3.0456 & 16.8372 & 0.7578 & 1.7568 & 1.6434 \\
& $\%$ & 0.090 & 0.737 & 0.965 & 5.333 & 0.240 & 0.556 & 0.521 \\
\hline \multirow{2}{*}{ G. Sparse woody vegetation } & $\mathrm{km}^{2}$ & 0.0765 & 0.0225 & 0.0756 & 1.4418 & 0.1296 & 0.0441 & 0.7659 \\
& $\%$ & 0.024 & 0.007 & 0.024 & 0.457 & 0.041 & 0.014 & 0.243 \\
\hline
\end{tabular}


Table 12. Matrix of land use-cover changes from 1986 to 2000, in the adjacent area of Natural Protected Area Altas Cumbres (NPAAC). Victoria, Tamaulipas, Mexico.

\begin{tabular}{|c|c|c|c|c|c|c|c|c|c|}
\hline & & & \multicolumn{7}{|c|}{2000} \\
\hline & & & A & B & $\mathrm{C}$ & $\mathbf{D}$ & E & $\mathbf{F}$ & G \\
\hline \multirow{14}{*}{1986} & \multirow{2}{*}{ A. Urban/bare soil areas } & $\mathrm{km}^{2}$ & 32.7726 & 0.2457 & 0.2502 & 1.9872 & 12.1203 & 2.529 & 7.9182 \\
\hline & & $\%$ & 4.331 & 0.032 & 0.033 & 0.263 & 1.602 & 0.334 & 1.046 \\
\hline & \multirow{2}{*}{ B. Temperate forests } & $\mathrm{km}^{2}$ & 0.7443 & 120.1194 & 14.7339 & 19.638 & 0.0648 & 0.3798 & 2.2518 \\
\hline & & $\%$ & 0.098 & 15.873 & 1.947 & 2.595 & 0.009 & 0.050 & 0.298 \\
\hline & \multirow{2}{*}{ C. Tropical vegetation } & $\mathrm{km}^{2}$ & 1.7721 & 13.0743 & 54.6534 & 14.6142 & 2.178 & 1.6443 & 8.6427 \\
\hline & & $\%$ & 0.234 & 1.728 & 7.222 & 1.931 & 0.288 & 0.217 & 1.142 \\
\hline & \multirow{2}{*}{ D. Scrub vegetation } & $\mathrm{km}^{2}$ & 8.5581 & 28.1538 & 40.6359 & 76.275 & 25.4556 & 9.234 & 62.1486 \\
\hline & & $\%$ & 1.131 & 3.720 & 5.370 & 10.080 & 3.364 & 1.220 & 8.213 \\
\hline & \multirow{2}{*}{ E. Sparse herbaceous vegetation } & $\mathrm{km}^{2}$ & 13.9518 & 0.0684 & 1.4913 & 5.2884 & 17.2404 & 4.5855 & 19.6227 \\
\hline & & $\%$ & 1.844 & 0.009 & 0.197 & 0.699 & 2.278 & 0.606 & 2.593 \\
\hline & \multirow{2}{*}{ F. Dense herbaceous vegetation } & $\mathrm{km}^{2}$ & 6.0903 & 0.5976 & 8.0271 & 21.5118 & 11.2653 & 6.7374 & 18.819 \\
\hline & & $\%$ & 0.805 & 0.079 & 1.061 & 2.843 & 1.489 & 0.890 & 2.487 \\
\hline & \multirow{2}{*}{ G. Sparse woody vegetation } & $\mathrm{km}^{2}$ & 4.9644 & 0.072 & 7.3197 & 8.3529 & 10.8756 & 3.3471 & 23.7087 \\
\hline & & $\%$ & 0.656 & 0.010 & 0.967 & 1.104 & 1.437 & 0.442 & 3.133 \\
\hline
\end{tabular}

\subsection{Land Use-Cover Changes from 2000 to 2005}

For 2005 , more than $62 \%$ of the total NPAAC remained apparently unchanged since 2000 , as there was a persistence of $101.6154 \mathrm{~km}^{2}$ of Scrub vegetation and $97.7238 \mathrm{~km}^{2}$ of Temperate forests. The highest proportion of transition occurred in Tropical vegetation $\left(22.0383 \mathrm{~km}^{2}, 6.98 \%\right)$ and Temperate forests $\left(14.6043 \mathrm{~km}^{2}, 4.63 \%\right)$, in which both types of cover modified to the category of Scrub vegetation in 2005 (Table 13). The Scrub vegetation showed the highest value of persistence in the adjacent area $\left(110.2581 \mathrm{~km}^{2}, 14.57 \%\right)$, followed by Temperate forests $\left(124.9911 \mathrm{~km}^{2}, 16.52 \%\right)$ and Tropical vegetation $\left(78.7797 \mathrm{~km}^{2}, 10.41 \%\right)$. Also, in the adjacent area, the greatest contribution to the Scrub vegetation category from 2000 to 2005 , was given by the transition of $48.3093 \mathrm{~km}^{2}$ of Sparse woody vegetation $(6.38 \%)$ and $34.1064 \mathrm{~km}^{2}$ of Tropical vegetation $(4.51 \%)$ (Table 14$)$.

Table 13. Matrix of land use-cover changes from 2000 to 2005, in Natural Protected Area Altas Cumbres (NPAAC). Victoria, Tamaulipas, Mexico.

\begin{tabular}{|c|c|c|c|c|c|c|c|c|c|}
\hline & & & \multicolumn{7}{|c|}{2005} \\
\hline & & & $\mathbf{A}$ & B & $\mathrm{C}$ & D & E & $\mathbf{F}$ & G \\
\hline \multirow{14}{*}{2000} & \multirow[b]{2}{*}{ A. Urban/bare soil areas } & $\mathrm{km}^{2}$ & 1.0107 & 0.0072 & 0.0054 & 0.1719 & 0.7542 & 0.0225 & 0.3204 \\
\hline & & $\%$ & 0.320 & 0.002 & 0.002 & 0.054 & 0.239 & 0.007 & 0.101 \\
\hline & \multirow{2}{*}{ B. Temperate forests } & $\mathrm{km}^{2}$ & 0.0963 & 97.7238 & 6.4593 & 14.6043 & 0.1251 & 0 & 5.4153 \\
\hline & & $\%$ & 0.031 & 30.956 & 2.046 & 4.626 & 0.040 & 0.000 & 1.715 \\
\hline & \multirow{2}{*}{ C. Tropical vegetation } & $\mathrm{km}^{2}$ & 0.0117 & 3.5613 & 25.6806 & 22.0383 & 0.0171 & 0.0234 & 1.1826 \\
\hline & & $\%$ & 0.004 & 1.128 & 8.135 & 6.981 & 0.005 & 0.007 & 0.375 \\
\hline & \multirow{2}{*}{ D. Scrub vegetation } & $\mathrm{km}^{2}$ & 0.063 & 4.4838 & 6.0966 & 101.6154 & 1.341 & 0.6696 & 1.3806 \\
\hline & & $\%$ & 0.020 & 1.420 & 1.931 & 32.188 & 0.425 & 0.212 & 0.437 \\
\hline & \multirow{2}{*}{ E. Sparse herbaceous vegetation } & $\mathrm{km}^{2}$ & 0.1062 & 0.0036 & 0.0045 & 1.2258 & 0.7416 & 0.0522 & 0.2781 \\
\hline & & $\%$ & 0.034 & 0.001 & 0.001 & 0.388 & 0.235 & 0.017 & 0.088 \\
\hline & \multirow{2}{*}{ F. Dense herbaceous vegetation } & $\mathrm{km}^{2}$ & 0.0225 & 0 & 0.018 & 3.4533 & 0.2043 & 0.4194 & 0.0117 \\
\hline & & $\%$ & 0.007 & 0.000 & 0.006 & 1.094 & 0.065 & 0.133 & 0.004 \\
\hline & \multirow{2}{*}{ G. Sparse woody vegetation } & $\mathrm{km}^{2}$ & 0.0423 & 0.4158 & 0.5076 & 9.5346 & 0.3879 & 0.0099 & 3.3705 \\
\hline & & $\%$ & 0.013 & 0.132 & 0.161 & 3.020 & 0.123 & 0.003 & 1.068 \\
\hline
\end{tabular}


Table 14. Matrix of land use-cover changes from 2000 to 2005, in the adjacent area of Natural Protected Area Altas Cumbres (NPAAC). Victoria, Tamaulipas, Mexico.

\begin{tabular}{|c|c|c|c|c|c|c|c|c|c|}
\hline & & & \multicolumn{7}{|c|}{2005} \\
\hline & & & A & B & $\mathrm{C}$ & $\mathbf{D}$ & $\mathrm{E}$ & $\mathbf{F}$ & G \\
\hline \multirow{14}{*}{2000} & \multirow{2}{*}{ A. Urban/bare soil areas } & $\mathrm{km}^{2}$ & 56.52 & 0.0261 & 0.0153 & 1.6506 & 7.3872 & 2.0709 & 1.1835 \\
\hline & & $\%$ & 7.469 & 0.003 & 0.002 & 0.218 & 0.976 & 0.274 & 0.156 \\
\hline & \multirow{2}{*}{ B. Temperate forests } & $\mathrm{km}^{2}$ & 0.5085 & 124.9911 & 8.1621 & 18.8568 & 0.2997 & 0.0027 & 9.5103 \\
\hline & & $\%$ & 0.067 & 16.517 & 1.079 & 2.492 & 0.040 & 0.000 & 1.257 \\
\hline & \multirow{2}{*}{ C. Tropical vegetation } & $\mathrm{km}^{2}$ & 0.8082 & 3.6837 & 78.7797 & 34.1064 & 1.0683 & 1.5795 & 7.0857 \\
\hline & & $\%$ & 0.107 & 0.487 & 10.411 & 4.507 & 0.141 & 0.209 & 0.936 \\
\hline & \multirow{2}{*}{ D. Scrub vegetation } & $\mathrm{km}^{2}$ & 1.5066 & 5.1885 & 10.4922 & 110.2581 & 7.1451 & 8.0343 & 5.0427 \\
\hline & & $\%$ & 0.199 & 0.686 & 1.387 & 14.570 & 0.944 & 1.062 & 0.666 \\
\hline & \multirow{2}{*}{ E. Sparse herbaceous vegetation } & $\mathrm{km}^{2}$ & 12.7647 & 0.0027 & 0.1935 & 14.7159 & 31.518 & 13.0806 & 6.9246 \\
\hline & & $\%$ & 1.687 & 0.000 & 0.026 & 1.945 & 4.165 & 1.729 & 0.915 \\
\hline & \multirow{2}{*}{ F. Dense herbaceous vegetation } & $\mathrm{km}^{2}$ & 1.4076 & 0 & 0.2142 & 10.5714 & 8.0685 & 6.6519 & 1.5435 \\
\hline & & $\%$ & 0.186 & 0.000 & 0.028 & 1.397 & 1.066 & 0.879 & 0.204 \\
\hline & \multirow{2}{*}{ G. Sparse woody vegetation } & $\mathrm{km}^{2}$ & 7.3575 & 0.7623 & 6.4503 & 48.3093 & 24.0156 & 7.5969 & 48.6198 \\
\hline & & $\%$ & 0.972 & 0.101 & 0.852 & 6.384 & 3.174 & 1.004 & 6.425 \\
\hline
\end{tabular}

\subsection{Land Use-Cover Changes from 2005 to 2015}

During the last period, the greatest proportion of preserved area was represented by Scrub vegetation, with a persistence of $130.7376 \mathrm{~km}^{2}$ (41.41\%) from 2005 to 2015 , as well as $92.9799 \mathrm{~km}^{2}$ of Temperate forests $(29.45 \%)$. In other words, more than $70 \%$ of the total area within the NPAAC remained unchanged between 2000 and 2005. However, the Scrub vegetation category continued its tendency to increase, adding $13.13 \%$ as result of the conversion of $28.7802 \mathrm{~km}^{2}$ of Tropical vegetation $(9.12 \%)$ and $12.6441 \mathrm{~km}^{2}$ of Temperate forests (4.01\%) (Table 15).

Table 15. Matrix of land use-cover changes from 2005 to 2015, in Natural Protected Area Altas Cumbres (NPAAC). Victoria, Tamaulipas, Mexico.

\begin{tabular}{llccccccc}
\hline & & \multicolumn{7}{c}{$\mathbf{2 0 1 5}$} \\
\cline { 3 - 9 } & & $\mathbf{A}$ & $\mathbf{B}$ & $\mathbf{C}$ & $\mathbf{D}$ & $\mathbf{E}$ & $\mathbf{F}$ & $\mathbf{G}$ \\
\hline \multirow{2}{*}{ A. Urban/bare soil areas } & $\mathrm{km}^{2}$ & 0.8928 & 0.0855 & 0 & 0.0747 & 0.1368 & 0.1098 & 0.0531 \\
& $\%$ & 0.283 & 0.027 & 0.000 & 0.024 & 0.043 & 0.035 & 0.017 \\
\hline \multirow{2}{*}{ B. Temperate forests } & $\mathrm{km}^{2}$ & 0.063 & 92.9799 & 0.3897 & 12.6441 & 0.0009 & 0.0009 & 0.117 \\
& $\%$ & 0.020 & 29.453 & 0.123 & 4.005 & 0.000 & 0.000 & 0.037 \\
\hline \multirow{2}{*}{ C. Tropical vegetation } & $\mathrm{km}^{2}$ & 0.0828 & 1.9404 & 7.7139 & 28.7802 & 0.009 & 0.1638 & 0.0819 \\
& $\%$ & 0.026 & 0.615 & 2.443 & 9.117 & 0.003 & 0.052 & 0.026 \\
\hline \multirow{2}{*}{ D. Scrub vegetation } & $\mathrm{km}^{2}$ & 0.3096 & 13.1256 & 1.2933 & 130.7376 & 1.5543 & 4.9599 & 0.6633 \\
& $\%$ & 0.098 & 4.158 & 0.410 & 41.413 & 0.492 & 1.571 & 0.210 \\
\hline \multirow{2}{*}{ E. Sparse herbaceous vegetation } & $\mathrm{km}^{2}$ & 0.5922 & 0.0792 & 0 & 1.3896 & 0.4941 & 0.6732 & 0.3429 \\
& $\%$ & 0.188 & 0.025 & 0.000 & 0.440 & 0.157 & 0.213 & 0.109 \\
\hline \multirow{2}{*}{ F. Dense herbaceous vegetation } & $\mathrm{km}^{2}$ & 0.1152 & 0 & 0.0054 & 0.3735 & 0.0333 & 0.6696 & 0 \\
& $\%$ & 0.036 & 0.000 & 0.002 & 0.118 & 0.011 & 0.212 & 0.000 \\
\hline \multirow{2}{*}{ G. Sparse woody vegetation } & $\mathrm{km}^{2}$ & 0.306 & 5.4081 & 0.0171 & 4.6341 & 0.2286 & 0.3069 & 1.0584 \\
& $\%$ & 0.097 & 1.713 & 0.005 & 1.468 & 0.072 & 0.097 & 0.335 \\
\hline
\end{tabular}

The trends in the persistence values observed within the NPAAC and in the adjacent area were similar. The highest values obtained for Scrub vegetation and Temperate forests were $134.991 \mathrm{~km}^{2}$ $(17.84 \%)$ and $120.1104 \mathrm{~km}^{2}(15.87 \%)$, respectively. The highest proportions of modified area occurred in the transition from Tropical vegetation to Scrub vegetation $\left(27.3348 \mathrm{~km}^{2}, 3.61 \%\right)$, as well as in the $26.6436 \mathrm{~km}^{2}$ transition from Scrub vegetation to Dense herbaceous vegetation (3.52\%) (Table 16). 
Table 16. Matrix of land use-cover changes from 2005 to 2015, in the adjacent area of Natural Protected Area Altas Cumbres (NPAAC). Victoria, Tamaulipas, Mexico.

\begin{tabular}{|c|c|c|c|c|c|c|c|c|c|}
\hline & & & \multicolumn{7}{|c|}{2015} \\
\hline & & & A & B & $\mathrm{C}$ & $\mathbf{D}$ & $\mathrm{E}$ & $\mathbf{F}$ & G \\
\hline \multirow{8}{*}{2005} & \multirow{2}{*}{ A. Urban/bare soil areas } & $\mathrm{km}^{2}$ & 64.413 & 0.2205 & 0.0144 & 0.7101 & 7.9929 & 2.9016 & 4.6206 \\
\hline & & $\%$ & 8.512 & 0.029 & 0.002 & 0.094 & 1.056 & 0.383 & 0.611 \\
\hline & \multirow{2}{*}{ B. Temperate forests } & $\mathrm{km}^{2}$ & 0.7308 & 120.1104 & 0.7065 & 12.6045 & 0.0036 & 0.0198 & 0.4788 \\
\hline & & $\%$ & 0.097 & 15.872 & 0.093 & 1.666 & 0.000 & 0.003 & 0.063 \\
\hline & \multirow{2}{*}{ C. Tropical vegetation } & $\mathrm{km}^{2}$ & 1.7487 & 3.5073 & 63.8235 & 27.3348 & 2.0772 & 4.6845 & 1.1313 \\
\hline & & $\%$ & 0.231 & 0.463 & 8.434 & 3.612 & 0.274 & 0.619 & 0.149 \\
\hline & \multirow{2}{*}{ D. Scrub vegetation } & $\mathrm{km}^{2}$ & 7.4385 & 17.6724 & 14.931 & 134.991 & 21.1257 & 26.6436 & 15.6663 \\
\hline & & $\%$ & 0.983 & 2.335 & 1.973 & 17.839 & 2.792 & 3.521 & 2.070 \\
\hline & \multirow{2}{*}{ E. Sparse herbaceous vegetation } & $\mathrm{km}^{2}$ & 13.2255 & 0.0972 & 0.4986 & 5.2263 & 32.1102 & 14.832 & 13.5126 \\
\hline & & $\%$ & 1.748 & 0.013 & 0.066 & 0.691 & 4.243 & 1.960 & 1.786 \\
\hline & \multirow{2}{*}{ F. Dense herbaceous vegetation } & $\mathrm{km}^{2}$ & 3.9294 & 0 & 1.1646 & 5.1912 & 13.5495 & 12.9087 & 2.2734 \\
\hline & & $\%$ & 0.519 & 0.000 & 0.154 & 0.686 & 1.791 & 1.706 & 0.300 \\
\hline & \multirow{2}{*}{ G. Sparse woody vegetation } & $\mathrm{km}^{2}$ & 6.4863 & 6.0966 & 0.9738 & 13.7889 & 7.7823 & 4.4469 & 40.3353 \\
\hline & & $\%$ & 0.857 & 0.806 & 0.129 & 1.822 & 1.028 & 0.588 & 5.330 \\
\hline
\end{tabular}

\subsection{Total Land Use-Cover Changes from 1973 to 2015}

Of the total area covered in 1973, $70.128 \mathrm{~km}^{2}$ of Temperate forests $(22.21 \%)$ and $62.3133 \mathrm{~km}^{2}$ of Scrub vegetation (19.74\%) were maintained in 2015, while persistence values for the remaining categories were very low. The total LULCC was noticeable towards the interior, as high percentages of transition from Tropical vegetation $\left(56.9466 \mathrm{~km}^{2}, 18.04 \%\right)$ and Temperate forests $\left(49.4757 \mathrm{~km}^{2}, 15.67 \%\right)$ to Scrub vegetation were obtained. In addition, $26.5581 \mathrm{~km}^{2}$ of Tropical vegetation and $14.9976 \mathrm{~km}^{2}$ of Scrub vegetation were modified to Temperate forests from 1973 to 2015 (Table 17).

Table 17. Matrix of land use-cover changes from 1973 to 2015, in Natural Protected Area Altas Cumbres (NPAAC). Victoria, Tamaulipas, Mexico.

\begin{tabular}{llccccccc}
\hline & & \multicolumn{7}{c}{$\mathbf{2 0 1 5}$} \\
\cline { 3 - 9 } & & $\mathbf{A}$ & $\mathbf{B}$ & $\mathbf{C}$ & $\mathbf{D}$ & $\mathbf{E}$ & $\mathbf{F}$ & $\mathbf{G}$ \\
\hline \multirow{2}{*}{ A. Urban/bare soil areas } & $\mathrm{km}^{2}$ & 0.3132 & 0.0477 & 0.0036 & 0.1755 & 0.1251 & 0.0711 & 0.1503 \\
& $\%$ & 0.099 & 0.015 & 0.001 & 0.056 & 0.040 & 0.023 & 0.048 \\
\hline \multirow{2}{*}{ B. Temperate forests } & $\mathrm{km}^{2}$ & 0.0189 & 70.128 & 0.5508 & 49.4757 & 0.0477 & 0.1773 & 0.0522 \\
& $\%$ & 0.006 & 22.214 & 0.174 & 15.672 & 0.015 & 0.056 & 0.017 \\
\hline \multirow{2}{*}{ C. Tropical vegetation } & $\mathrm{km}^{2}$ & 0.2178 & 26.5581 & 5.6826 & 56.9466 & 0.2988 & 1.9242 & 0.117 \\
& $\%$ & 0.069 & 8.413 & 1.800 & 18.039 & 0.095 & 0.610 & 0.037 \\
\hline \multirow{2}{*}{ D. Scrub vegetation } & $\mathrm{km}^{2}$ & 0.5661 & 14.9976 & 2.799 & 62.3133 & 1.2123 & 3.3381 & 0.7785 \\
& $\%$ & 0.179 & 4.751 & 0.887 & 19.739 & 0.384 & 1.057 & 0.247 \\
\hline \multirow{2}{*}{ E. Sparse herbaceous vegetation } & $\mathrm{km}^{2}$ & 0.3825 & 0.1161 & 0.0081 & 0.5832 & 0.1854 & 0.1278 & 0.3528 \\
& $\%$ & 0.121 & 0.037 & 0.003 & 0.185 & 0.059 & 0.040 & 0.112 \\
\hline \multirow{2}{*}{ F. Dense herbaceous vegetation } & $\mathrm{km}^{2}$ & 0.3906 & 0.8343 & 0.1593 & 5.2074 & 0.1791 & 0.8829 & 0.0558 \\
& $\%$ & 0.124 & 0.264 & 0.050 & 1.650 & 0.057 & 0.280 & 0.018 \\
\hline \multirow{2}{*}{ G. Sparse woody vegetation } & $\mathrm{km}^{2}$ & 0.4725 & 0.9369 & 0.216 & 3.9321 & 0.4086 & 0.3627 & 0.81 \\
& $\%$ & 0.150 & 0.297 & 0.068 & 1.246 & 0.129 & 0.115 & 0.257 \\
\hline
\end{tabular}

In the adjacent area, there was a persistence of $79.9074 \mathrm{~km}^{2}(10.56 \%)$ of Temperate forests and $61.3359 \mathrm{~km}^{2}(8.11 \%)$ of Scrub vegetation that remained unchanged from 1973 to 2015 . The persistence of $26.0856 \mathrm{~km}^{2}$ of Urban and bare soil areas was also remarkable. In contrast, a transition from $53.4564 \mathrm{~km}^{2}(7.06 \%)$ of Temperate forests and $51.0345 \mathrm{~km}^{2}(6.74 \%)$ of Tropical vegetation to Scrub vegetation was observed. In addition, $34.5231 \mathrm{~km}^{2}$ of Tropical vegetation and $28.2636 \mathrm{~km}^{2}$ of Scrub vegetation were modified to Temperate forest, while $25.8768 \mathrm{~km}^{2}$ of Scrub vegetation changed to 
Tropical vegetation. Moreover, $22.3407 \mathrm{~km}^{2}$ of Scrub vegetation were modified to Urban and bare soil areas. The high percentage of transition from Scrub vegetation in 1973 to Sparse herbaceous, Dense herbaceous, and Sparse woody vegetation in 2015 was also notorious in the adjacent area (Table 18).

Table 18. Matrix of land use-cover changes from 1973 to 2015, in the adjacent area of Natural Protected Area Altas Cumbres (NPAAC). Victoria, Tamaulipas, Mexico.

\begin{tabular}{llccccccc}
\hline & & \multicolumn{7}{c}{$\mathbf{2 0 1 5}$} \\
\cline { 3 - 9 } & & $\mathbf{A}$ & $\mathbf{B}$ & $\mathbf{C}$ & $\mathbf{D}$ & $\mathbf{E}$ & $\mathbf{F}$ & $\mathbf{G}$ \\
\hline \multirow{2}{*}{ A. Urban/bare soil areas } & $\mathrm{km}^{2}$ & 26.0856 & 0.0567 & 0.2538 & 2.9466 & 7.8606 & 3.1248 & 13.9788 \\
& $\%$ & 3.447 & 0.007 & 0.034 & 0.389 & 1.039 & 0.413 & 1.847 \\
\hline \multirow{2}{*}{ B. Temperate forests } & $\mathrm{km}^{2}$ & 0.2151 & 79.9074 & 1.6758 & 53.4564 & 0.2529 & 0.7398 & 0.126 \\
& $\%$ & 0.028 & 10.560 & 0.221 & 7.064 & 0.033 & 0.098 & 0.017 \\
\hline \multirow{2}{*}{ C. Tropical vegetation } & $\mathrm{km}^{2}$ & 5.6025 & 34.5231 & 35.2881 & 51.0345 & 7.0938 & 10.7775 & 2.889 \\
& $\%$ & 0.740 & 4.562 & 4.663 & 6.744 & 0.937 & 1.424 & 0.382 \\
\hline \multirow{2}{*}{ D. Scrub vegetation } & $\mathrm{km}^{2}$ & 22.3407 & 28.2636 & 25.8768 & 61.3359 & 23.2371 & 20.106 & 19.7748 \\
& $\%$ & 2.952 & 3.735 & 3.420 & 8.105 & 3.071 & 2.657 & 2.613 \\
\hline \multirow{2}{*}{ E. Sparse herbaceous vegetation } & $\mathrm{km}^{2}$ & 15.9732 & 0.3906 & 3.3597 & 6.2766 & 15.8184 & 7.4421 & 17.0631 \\
& $\%$ & 2.111 & 0.052 & 0.444 & 0.829 & 2.090 & 0.983 & 2.255 \\
\hline \multirow{2}{*}{ F. Dense herbaceous vegetation } & $\mathrm{km}^{2}$ & 14.3712 & 0.9846 & 8.1153 & 12.4983 & 16.3782 & 15.4143 & 4.6431 \\
& $\%$ & 1.899 & 0.130 & 1.072 & 1.652 & 2.164 & 2.037 & 0.614 \\
\hline \multirow{2}{*}{ G. Sparse woody vegetation } & $\mathrm{km}^{2}$ & 13.3839 & 3.5784 & 7.5429 & 12.2985 & 14.0004 & 8.8326 & 19.5435 \\
& $\%$ & 1.769 & 0.473 & 0.997 & 1.625 & 1.850 & 1.167 & 2.583 \\
\hline
\end{tabular}

\subsection{Successional Stages of the Dominant Types of Vegetation}

Within the NPAAC polygon, the greatest proportion of cover (47.41\%) was characterized by the dominance of Native vegetation without a linear process of succession, with $119.439 \mathrm{~km}^{2}$ corresponding to the category of Scrub vegetation $(37.83 \%)$, and $30.2643 \mathrm{~km}^{2}$ of Temperate forests-Tropical vegetation $(9.58 \%)$. However, a high proportion $(23.69 \%)$ was represented by the categories of Native Temperate forests $\left(50.2191 \mathrm{~km}^{2}\right)$ and Native Scrub vegetation $\left(24.5682 \mathrm{~km}^{2}\right)$, which were preserved for more than 42 years. Although it presented very low coverage values, the same tendency occurred for Tropical vegetation, since the largest area for this category was occupied by Native areas with more than 42 years of conservation $\left(3.5874 \mathrm{~km}^{2}\right)$. High coverage values were also observed for Temperate forests with 10 years of succession $\left(18.6984 \mathrm{~km}^{2}\right)$, as well as for Scrub vegetation $\left(14.7213 \mathrm{~km}^{2}\right)$ with 29 and 15 years of succession $\left(10.1916 \mathrm{~km}^{2}\right)$. For the remaining categories, the value of the occupied area was below $10 \mathrm{~km}^{2}$ (Figure 5, Appendix A-Figure A6).

In the adjacent area, the Modified (with disturbance in 2015) and Permanently disturbed areas (persistence of disturbance since 1973) were the successional categories with the largest proportion (43.22\%), occupying 127.9575 and $199.1115 \mathrm{~km}^{2}$, respectively. Furthermore, a high proportion of Scrub vegetation without a linear succession process $\left(116.6778 \mathrm{~km}^{2}\right)$ was observed. The tendency of the adjacent area to exhibit higher values of secondary vegetation cover was remarkable. For example, although $60.9552 \mathrm{~km}^{2}$ was occupied by Native Temperate forests, a significant proportion of Temperate forests was also occupied by areas with 42 and 29 years of succession. In the case of Tropical vegetation, similar coverage values were found in areas with 10,29 and 42 years of succession, as well as in Native areas. Finally, both Scrub vegetation categories with 10 and 15 years of succession and, to a lesser extent, Native Scrub areas with more than 42 years without disturbance, were dominant with respect to areas with 29 and 42 years of succession of this type of vegetation (Figure 5, Appendix A-Figure A6). 

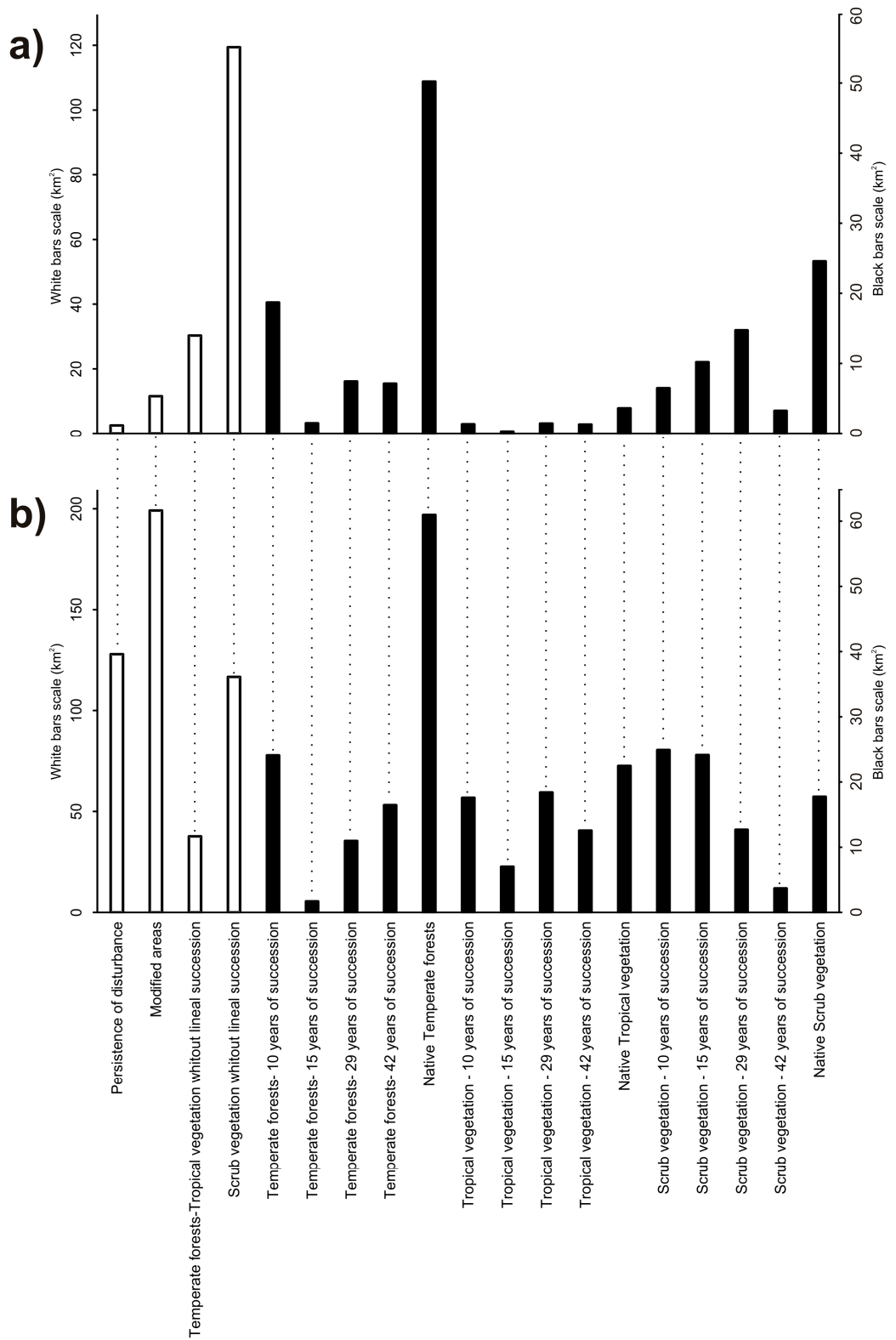

Figure 5. Occupied area $\left(\mathrm{km}^{2}\right)$ for each successional category in 2015 within the (a) Natural Protected Area Altas Cumbres and (b) its adjacent area. Victoria, Tamaulipas, Mexico.

\section{Discussion}

\subsection{Land Use-Cover Changes within the Natural Protected Area Altas Cumbres and Its Adjacent Area}

The lowest values of the accuracy in the classification and Kappa index were obtained for the MSS image of 1973; this may have been because of its lower spatial resolution compared to the ETM and OLI images. It may generate confusion in the spectral signature of categories, and complicate classification [4]. However, assessment and classification of the years/stages considered in our study (including the scene of 1973) are reliable, since percentages of overall accuracy were higher than $85 \%$ [61] and Kappa index values were close to 1.0 [58]. Therefore, these results support both the land use-change and successional analysis herein conducted.

The largest proportion of the area within the NPAAC polygon in 2015 corresponded to Native Temperate forests and Scrub vegetation with persistence since 1973, suggesting that extensive areas of several types of vegetation included in both categories (such as pine, oak, and pine-oak forests, as well 
as submontane scrub, amongst others), are well preserved. Nevertheless, large areas of Temperate forests and other categories showed a gradual transition to Scrub vegetation, with an appreciable decrease in Tropical vegetation cover from 1973 to 2015. These results agree with regional tendencies observed in Mexico, since change rate and loss of vegetal cover in Temperate forests is much lower than that for Tropical forests [40]. This reduction in native vegetal cover is not exclusive from our study region; it is rather a worldwide pattern [6] that has increased in recent years in NPAs and different areas from other countries $[8,9,62,63]$. Although the causes of these changes were not assessed in this work, recent studies on LULCC $[12,25,26]$ that include the evaluation of NPAs $[27,28]$ and their surrounding areas [31] have shown that deforestation due to overexploitation, uncontrolled logging, agricultural activities, consumer demand, fires, pests, and urban growth, as well as natural phenomena arising from climate change, are some of the main factors that influence the loss of vegetation in Mexico [2]. In other areas, the increase in land cover changes has been caused by the rapid population growth, the multiplication of human settlements, and regional economic development [8-10,64]. Likewise, the highest percentages of change and transition occurred between 1973, 1986 and 2000, coincide with a period of high deforestation in Mexico [34,40], as proposed in one of the hypotheses raised in this work. However, contrary to our second hypothesis, there was a significant decrease of Tropical vegetation within the NPAAC from 2005 to 2015, even though the official decree in 1997 [41] suggested that modification rates from 2000 onwards would be lower. Inefficiency of NPAs to contain and prevent LULCC has been observed previously in other areas in Mexico [29], but it is possible that the recent creation of an official management plan for the NPAAC [33,42] will contribute to a future decline in LULCC. This may need to be evaluated and quantified in the coming years.

It has been documented that LULCC occurring in adjacent areas of NPAs are of major transcendence, since habitats and resources that contribute to their functioning are located outside their limits in unprotected areas [36]. This includes also the presence of urban areas and their influence on the adjacent ecosystems $[11,36,63]$. Hence, there are certain factors concerning the adjacent areas studied whose influence is considered relevant for the NPAAC. First, agriculture: this activity was well represented during 1973 and 1986, and it was reflected in the large coverage of Dense herbaceous vegetation category in that period. Then, the decline in cultivated areas in 2000 corresponds with the increase in Sparse vegetation categories (herbaceous and woody vegetation) in the same year, and suggests the abandonment of agricultural plantations. However, since 2005, agriculture has started increasing again, and the consequences stemming from this have yet to be assessed. Second, the significant and constant buildup of urban areas from 1973 to 2015 has led to an augmentation of human settlements towards the eastern limits of the NPAAC [42,44]. Both results are consistent with tendencies observed in other countries, since the number of agricultural and urban areas has increased in recent years $[9,62,63]$ as a consequence of the raising in food demand due to population growth [6]. Lastly, the notable decline of Tropical vegetation: in 1973, this category embodied several $\mathrm{km}^{2}$ of extension towards the north, south, and eastern limits of NPAAC, and also around the main urban area. Nevertheless, the increase in the number of bare areas and areas assigned for urban growth that appeared from 1986 to 2015 caused fragmentation and a significant reduction of this type of vegetation. By 2015, Tropical vegetation was restricted mainly to the skirts of the mountain range, between the western portion of the urban area and the eastern boundary of the NPAAC. Several other patches remaining in nearby areas were rapidly diminishing. Indeed, the increase in fragmentation of vegetation [8] and land use change are some of the main causes of biodiversity loss worldwide [6]. Therefore, it is of great relevance that future studies aim at evaluating the state of the current communities, both within and in adjacent areas of the NPAAC, to assess the response of the different vegetation categories to land use changes.

\subsection{Successional Stages of the Main Types of Vegetation in the Natural Protected Area Altas Cumbres}

The process of secondary succession in vegetal communities is characterized by a modification of vegetation, subsequent to a disturbance [65-67], and in the absence of new changes, the disturbed 
areas over time may present and recover attributes similar to those of the original areas [68]. Despite the fact that the successional process is not always unidirectional and can follow different routes $[67,69]$ and operate according to different causes [70], for this study we considered the secondary succession only as the process of recovery of vegetation [66], without taking into account the route or factors that caused it. Therefore, for this purpose, those areas with modified land cover (for example crops and urban areas), without vegetation (bare soil areas), or characterized by fast-grow pioneer species (grasslands, sparse or dense herbaceous vegetation, among others) were selected as disturbance areas or primary successional stages. Likewise, vegetation types in the category of Scrub vegetation were considered as an initial successional stage for Tropical vegetation and Temperate forests, since it has been observed that development of these communities after disturbance is preceded by scrub vegetation [59]. Thus, the presence of a disturbed area or an early successional stage in a satellite image, and its transition to Scrub, Tropical vegetation or Temperate forest in the next temporal stage, suggests a recovery process in that zone or pixel analyzed between a temporary stage and another. In this way, it is possible to reconstruct the history of LULCC that occurred or may be occurring in a given area.

The succession processes considered in this work are related to previous evidence of post-disturbance changes in vegetal communities, which have been extensively analyzed worldwide, including in Mexico. After major disturbances where the removal of vegetation was complete, or nearly so [71], it has been recognized that early stages of succession post disturbance are characterized by dominance of pioneer species such as grasses, shrubs, and other short-lived species [72,73]. Therefore, besides the evidently disturbed bare-soil areas, we include the low and dense herbaceous vegetation in the disturbance category as early transition stages for Scrub vegetation, because the abandonment of cultivars, grasslands and other disturbed areas is related to recovery of the vegetation [74]. In this regard, evidence shows that abandonment of cultivated areas and pasture fields results in the development of thorny vegetation [75], this being one of the communities considered within the Scrub vegetation in our study. In Mexico, it has been observed that early succession stages are characterized by a dominance of herbaceous and shrubs for both Tropical vegetation [76] and Temperate forests [77]. In addition, scrub vegetation exists as an ecotone with areas of these two vegetal communities [78]. In late succession stages, the transition from shrubs to woody species is a common pattern [73], and other studies have shown that the increase in successional time favors long-lived and taller trees [72], resulting in a significant decrease of shrubs [79]. In summary, this provides ecological evidence for the transition processes considered in our study, in which Scrub vegetation and other categories may precede both Tropical vegetation and Temperate forests in the succession. However, the process of secondary succession is widely recognized as nonlinear $[67,69,71]$, and areas with similar environmental constraints and disturbance conditions, despite being closer to each other, could exhibit very distinct successional trajectories [80]. We try to overcome this drawback by including both categories of Tropical vegetation-Temperate forests and Scrub vegetation without linear succession, in which we include areas with transitions between different vegetation communities.

The analysis of succession and detection of secondary forests based on multiple layers and scenes of different years has already been used; similarly, other studies have also worked with five or even more temporal stages [22,23]. In this sense, the use of Landsat satellite images for the analysis of LULCC is a widely used method [3,5,8,9,62], including multitemporal approaches which encompasses several stages $[4,14-21,64,81]$. However, despite the use of five temporal stages (satellite images of $1973,1986,2000,2005$ and 2015), it is necessary to recognize the potential limitations of this study, since the disturbances presented between these stages in years not considered could influence the results. For example, an area/pixel categorized with 15 years of succession indicates a category of disturbance in 2000 and the presence of recovered vegetation (Scrub, Tropical or Temperate) in 2005 and 2015. Nevertheless, there may have been disturbance events after 2000 or 2005 that are not considered, and therefore the successional time for such an area in 2015 would be lower. Although it is impossible to determine the exact recovery time, it is guaranteed that the vegetation presents a successional time 
interval of about 15 years maximum. In addition, the images used as a basis for cross-tabulation presented high values of correct classification, which helps the validation of the succession analysis. It is not excluded, however, that some artifacts could exist (as in any other study) in the classification and validation process that are the basis for our succession analysis. Some of the variations we found in LULC between years could be related to the date of the images, since the scene of 1973 used (it was the only one available) corresponds to the starting wet season, while the others belong to the dry season. Such factors could be related to change patterns of LULC in our study, but it may be of minor relevance for the successional analysis conducted since the seven delimited categories were separated in disturbance and native vegetation for that analysis. For example, it is possible that differences between some areas of Sparse and Dense herbaceous vegetation could not exist, as both are related to agricultural activities; however, both were also included in the disturbance category. Therefore, it does not influence the successional patterns found with our methodological approach. Nevertheless, we suggest that future studies performed in this or any other area could be improved by using more than one image (whenever available) per year of classification. Furthermore, it is highly recommended to conduct future evaluations in different sites of the study area that allow for the measurement of vegetation characteristics associated with the successional time, such as density of plants, diameter at breast height, or basal area [82], so that the patterns here proposed can be corroborated.

The Scrub vegetation (which includes submontane scrub and Tamaulipan thornscrub, and others) constitutes an endangered category of vegetation, despite being a dominant plant community in northeastern Mexico, as well as on the slopes of the Sierra Madre Oriental within the study area $[59,83,84]$. This type of vegetation has suffered great losses in Mexico, and at present, many areas of this vegetal cover have some degree of alteration, or are fragmented, distributed in mosaics with different successional stage $[85,86]$. A similar trend was observed in the NPAAC, since the cross-tabulation analysis showed that the Scrub without linear succession is currently the predominant category. It suggests that these areas recovered after disturbances, but experienced new modifications or different successional trajectories between different types of vegetation that culminated with the presence of Scrub vegetation in the most recent scene (year 2015). Also, it indicates that a large extension of the Scrub vegetation within the NPAAC corresponds to secondary vegetation. This is a relevant situation, since the LULCC analysis proved that much of this coverage comes from many modified and disturbed areas of Temperate forests that did not recuperate their original state and were covered in 2015 by Scrub vegetation. Similarly, Tropical vegetation was reduced almost entirely within the NPAAC, at present it is represented by only a few conserved remnants, and some areas with 42 or 29 years of succession, mainly in zones adjacent to rivers, while much of the original vegetation exhibited a transition to Scrub vegetation. This type of transition is a documented phenomenon, since after the disturbance, the scrub vegetation is one of the first stages of succession [59]. The high modification values observed in the region are similar to the general increase of secondary vegetation cover [22], since many vegetation types are undergoing high rates of change in other countries [62]. However, it is also possible that several areas in this category in 2015 represent transition zones, with Scrub vegetation elements mixed with elements of Temperate forests or Tropical vegetation (such as low subcaducifolious forest or low thorn forest). In this sense, it has been recognized that the submontane scrub forms transition zones with the low tropical semideciduous forest towards the lower areas and even with oak forest towards the upper parts of the NPAAC [44]; this is reflected in a mixture of the vegetation elements. Additionally, the presence of palm trees indicates a dominance of this plant community in other patches of native vegetation of submontane scrub and oak forests as a result of disturbance [42,44]. Future analyses may reveal whether these areas categorized as Scrub vegetation are natural ecotones, or represent disturbed areas in a successional process that can be reestablished in the coming years in the absence of new major disturbances.

As stated previously, large extensions of Temperate forests in the NPAAC were modified to Scrub vegetation through the evaluated period. In contrast, the remnants of these forests in 2015 are native areas that have remained unchanged since at least 1973, and the small proportion of this type of 
vegetation in a given successional stage contributes to an increase in species richness, since it has been observed that the presence of temperate plant communities with different succession times favors regeneration and allows for diversity [77]. Moreover, the spatial distribution of Temperate forests, both native areas and those with a successional process, was mostly concentrated in the northwestern part of the NPAAC, and agrees with the most recent categorization proposed in the official management plan for the study area [42], where the same region is recommended as an area for preservation and restoration of the oak-pine forest. Conversely, according to the management plan [42], most of the NPAAC renders a buffer zone, suggesting the occurrence of significant changes in that area during last years, as well as the presence of other types of secondary vegetation.

In the adjacent area to the NPAAC, the processes of disturbance and succession were more evident. In this case, the southwestern region is mainly a semi-arid zone, so the persistence of areas without dense vegetation was expected. However, an important urban area is located eastern of the NPAAC. This explains the large proportion of Modified areas in 2015 with respect to disturbance in 1973, as well as the presence of a greater extension of vegetation in different successional stages. As cited earlier in this study, the importance of adjacent areas for the interior of NPAs is well documented [11,36,63]. This is of major importance when considering the presence of Tropical vegetation by the boundaries between the urban western area and the NPAAC, since the type of vegetation is fragmented and is mostly secondary vegetation with 10,15, 29 or 42 years of succession, except for some preserved areas towards the north. For Temperate forests, it is evident that the larger proportion is occupied by native vegetation, as this plant community is distributed by the mountains, external to the NPAAC. However, some areas with 10, 29 and 42 years of succession are located around its boundaries, mostly by the western limit, close to the arid areas of the southwestern region. Scrub vegetation depicts important changes, and disturbances have occurred during recent years in the region, as evidenced by the fact that the proportion of native vegetation is lower than that observed for areas with 10 and 15 years of succession, with the vegetation being patches of vegetation distributed around the urban western area, and towards the north and south of the NPAAC. In this study, the categories of Scrub and Tropical vegetation included submontane scrub and low tropical semideciduous forest, which are some of the most important vegetation types and reservoirs of biological diversity [44]. The implications of these patterns for the NPAAC and its adjacent areas are related to the effects of the time of succession in species and communities. Studies on plants and their associated variables [7] indicate that the time of succession modifies the structure and composition of the species [22]. Additionally, areas with recent disturbance show different microclimate conditions, being hotter and drier than late successional areas, where a dense canopy cover favors higher relative humidity and a decline in temperature [87]. This is a significant implication for succession patterns within the NPAAC and its adjacent areas, as a high proportion of the actual cover of Tropical vegetation and Scrub vegetation represents secondary vegetation of recent succession time, which surely modifies the interactions within these communities. The evidence provided here calls attention to the urgency of assessing and quantifying the effect of succession time on species and biological groups on these vegetation patches, given the importance of the adjacent ecosystem processes towards the interior of the NPAs.

In summary, our results suggest that the study area is made up of a mosaic of patches and fragments of both native areas and secondary vegetation of different successional time, with this being an increasing tendency also in other countries [8,22], and a factor of major relevance because the dynamics of secondary forests are related to ecosystem processes [22]. The high transition rate of Temperate forests and Tropical vegetation to other land cover categories, as well as the constant disturbances in the Scrub vegetation within the NPAAC and its adjacent areas, points out the necessity for a deeper evaluation of the present communities. Since the increasing rates of land use-cover change are one of the main causes for biodiversity loss [6], it is expected that succession patterns are also evaluated within the framework of these studies. However, although secondary succession is a central issue for the analysis of biological communities related to post-disturbance events, it is not always addressed in studies concerning land use-cover changes, whether these are conducted in NPAs or 
not $[62,63]$. This is of major importance, because any analysis of land cover transition or persistence implies different processes of recovery or modification in vegetation and, more precisely, time of regeneration, which is more accentuated for multitemporal analysis $[3,8,9,14-19]$. Regardless of the method used to delimit the succession time or the presence of secondary vegetation $[20,22,23]$, we must stress the necessity of the evaluation of succession patterns in future studies of land-use cover changes, as was done in this study.

\subsection{Use of Successional Stages for Delimiting Chronosequences in the Natural Protected Area Altas Cumbres}

It is evident that LULCC and the time of succession or post-disturbance recovery have important consequences on species and ecological processes. For that reason, it is imperative to evaluate the status of the current populations and communities and determine their responses to such changes in the study area. However, most of the faunistic, floristic, and ecosystem-related studies in the NPAAC and its adjacent area are relatively recent, and the scarcity of previous work carried out in this region during the past decades makes an adequate comparison difficult. A frequent strategy for evaluating these changes is the use of chronosequences, which indirectly allow the study of succession processes in space, instead of time [69]. Historical and in situ vegetation differences may lead to bias in succession evaluation [88]. Therefore, it is necessary that the modification process of early successional stages occur under similar conditions to those observed for older sites. Thus, if the date of the initial disturbance and the subsequent history of the site (succession trajectory) are known, then chronosequences will be effective for assessing the recovery process of the communities after disturbances, over prolonged periods of time [69]. Several studies have evaluated changes in communities along successional gradients using a chronosequence approach; yet, the use of satellite images for such gradient delimitation is not always employed [68,79,89-92].

Based on the above arguments, and taking into account that the use and analysis of satellite images performed in our study allows us to know the approximate history of the succession (not the route or the involved process) at a given site, it is suggested and proposed that a similar method to the one used here may be considered for additional studies to delimit the age of such sites and the presence of secondary vegetation, so that they can be used as frameworks for the study of chronosequences. Even if the delimitation of the successional gradient is carried out over a large area such as the NPAAC, it is suggested that, when applying the chronosequence approach, the studies be confined to small areas, so that comparisons between distant sites are avoided even if they have the same age of succession. Finally, these results represent a first approach to the knowledge of the recovery status and successional time of main vegetation types in the NPAAC, as well as a preliminary approximation on the use of chronosequences for future evaluations of the successional dynamics on vegetation and other biological groups in the study area.

\section{Conclusions}

This work is the first analysis on LULCC for the NPAAC. This protected area in northeastern Mexico is endowed with unique biodiversity; therefore, its conservation is of primary importance. It was decreed as protected area in 1997; however, there was a significant reduction in Temperate forests and Tropical vegetation categories from 1973 to 2015, while the Scrub vegetation cover increased during the same period. In the adjacent area, there was a notable expansion of urban areas, as well as other categories of modified vegetation. This is relevant, since it has not been evaluated to date how these disturbances may influence the NPAAC interior and external ecosystem processes.

Through an analysis of the history of changes in the area, it was possible to delimit a successional time for the main vegetation types. Scrub vegetation, without linear succession, dominates the interior of the NPAAC, suggesting the presence of large disturbed areas of this plant communities, which may subsequently recover and modify again. The current vegetation in the adjacent area of the NPAAC is composed mostly of secondary and disturbed vegetation patches, with different times of succession. Future studies are necessary to evaluate the recovery process of these plant communities, as well 
as to study the effects of such modifications on the fauna. It is suggested that analysis of Landsat satellite images could be used in future work to detect fragments of secondary vegetation and delimit their approximate time of succession. The approach followed in this study can be replicated in other areas for estimating secondary succession. However, some recommendations are provided. First, Landsat data is not mandatory, any other type of image may be useful, and a higher resolution will greatly improve the results obtained. Second, as in any other analysis concerning satellite images, it is suggested that data belong to similar dates in order to avoid seasonality, since an erroneous land use-cover classification could affect the succession analysis. In this regard, it is necessary to explore if other classification methods, aside from the classified segmentation and maximum likelihood used in this study, could provide a more precise successional analysis. Third, the increase in the number of years/ages/steps evaluated will result in a less biased successional analysis. Lastly, the geographical extension of the evaluated area is considered of major importance when conducting the successional analysis. Although our study was carried out in a small area, we are certain that even a finer scale comprising only a few $\mathrm{km}^{2}$ would guarantee greater control over both the classification and validation methods, therefore improving significantly the succession analysis. If these approaches are implemented in small areas, they could be used as chronosequences, and may be useful in the analysis of the ecological succession and its effects on species groups.

Acknowledgments: This work was carried out within the framework of a Doctoral scholarship (No. 401277) granted by the Consejo Nacional de Ciencia y Tecnología (CONACYT) to the first author. We acknowledge facilities provided by the Tecnológico Nacional de México-Instituto Tecnológico de Cd. Victoria to accomplish this work. We greatly appreciate the comments and suggestions of two anonymous reviewers, which greatly improved this manuscript.

Author Contributions: Uriel Jeshua Sánchez-Reyes conceived and designed the study, wrote the paper, produced the land use-cover (LULC) maps, and developed the successional analysis methodology. Santiago Niño-Maldonado, Ludivina Barrientos-Lozano and Jacinto Treviño-Carreón advised on the successional analysis methodology, supervised validation of the LULC maps and contributed to the writing of manuscript (MS). All authors contributed equally to advice, discussion and revision of MS.

Conflicts of Interest: The authors declare no conflict of interest.

\section{Appendix A}

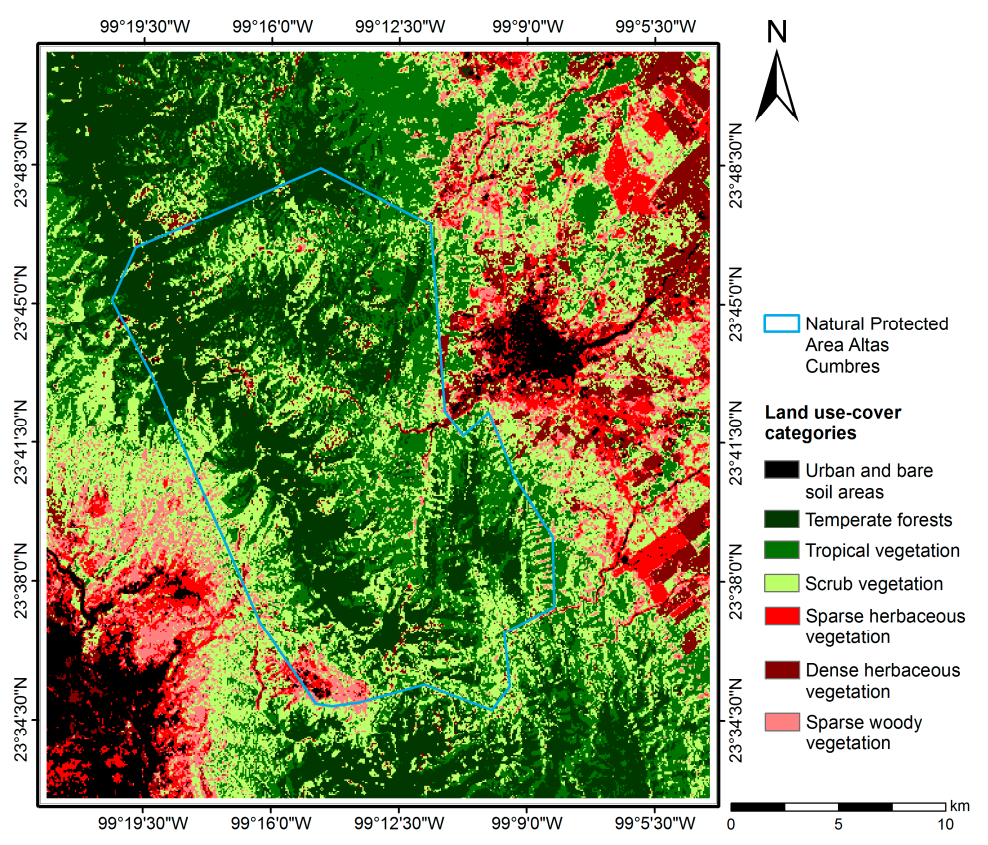

Figure A1. Land use-cover in 1973, Natural Protected Area Altas Cumbres and adjacent area. Victoria, Tamaulipas, Mexico. 


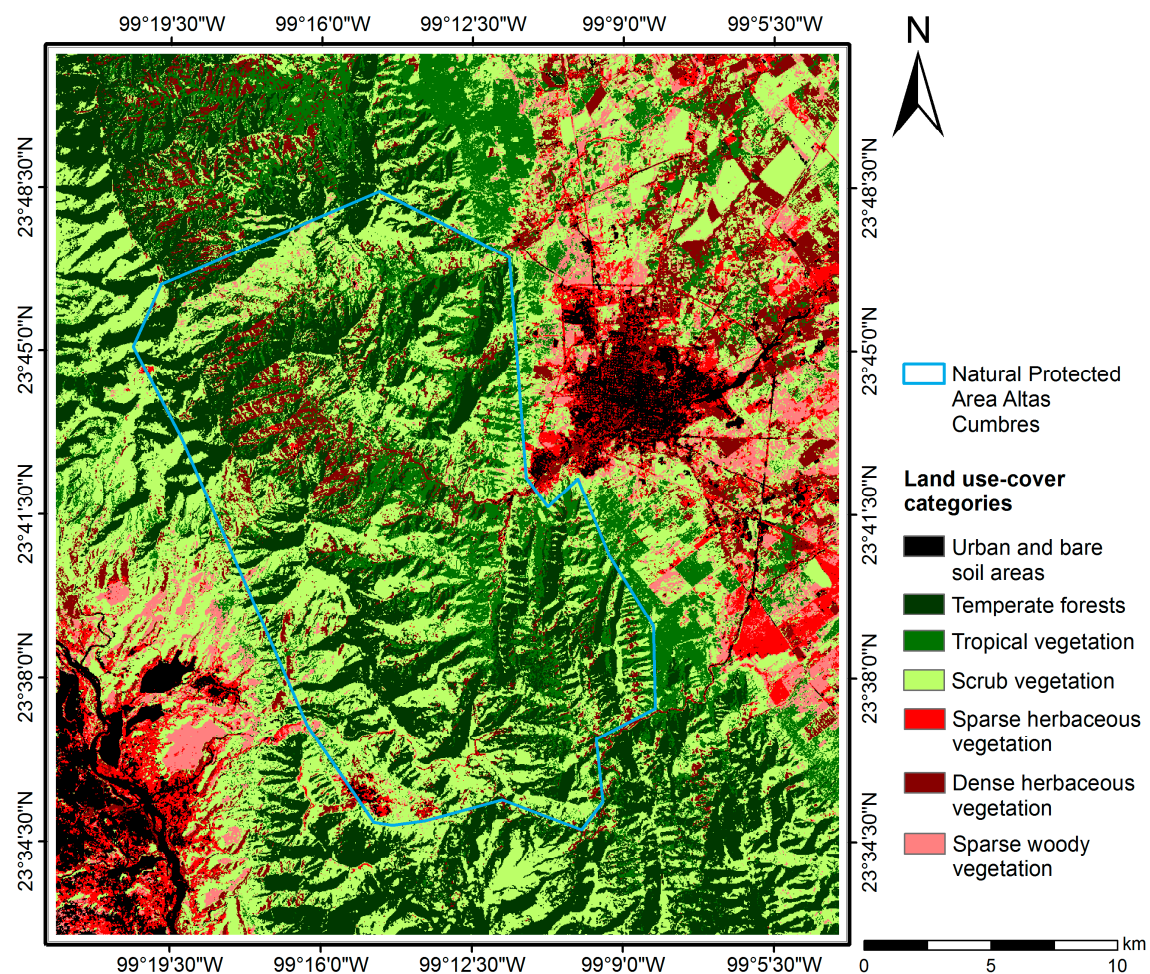

Figure A2. Land use-cover in 1986, Natural Protected Area Altas Cumbres and adjacent area. Victoria, Tamaulipas, Mexico.

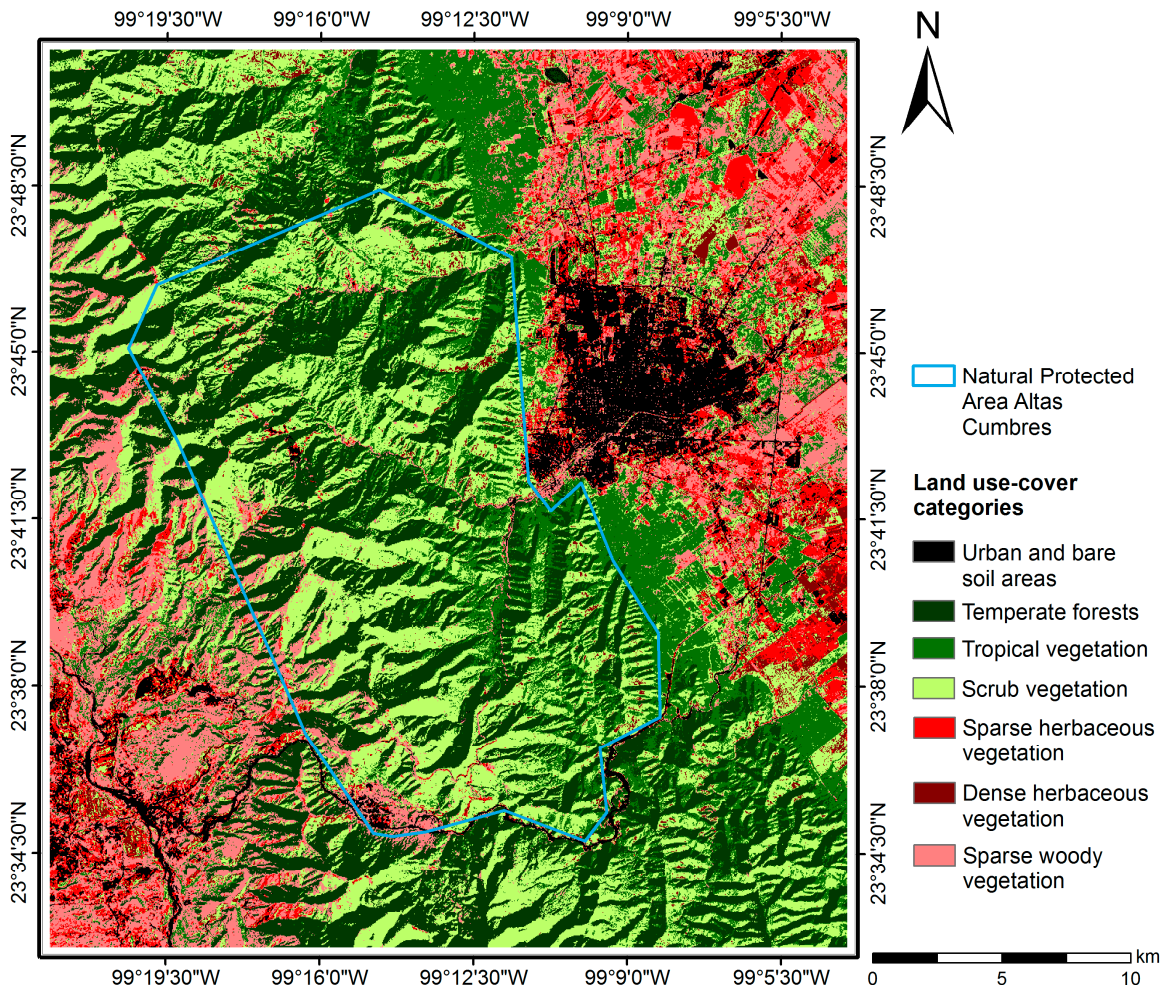

Figure A3. Land use-cover in 2000, Natural Protected Area Altas Cumbres and adjacent area. Victoria, Tamaulipas, Mexico. 


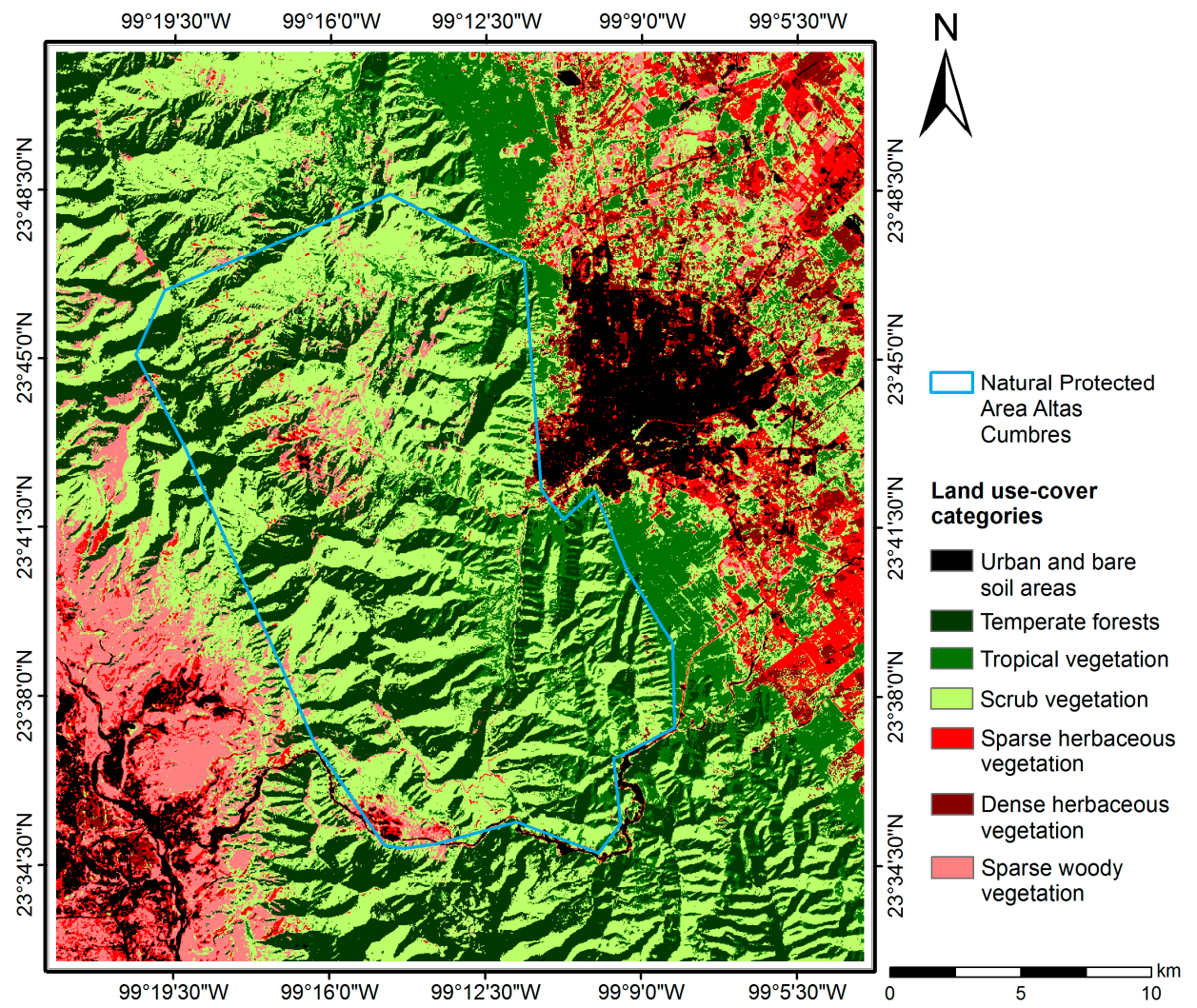

Figure A4. Land use-cover in 2005, Natural Protected Area Altas Cumbres and adjacent area. Victoria, Tamaulipas, Mexico.

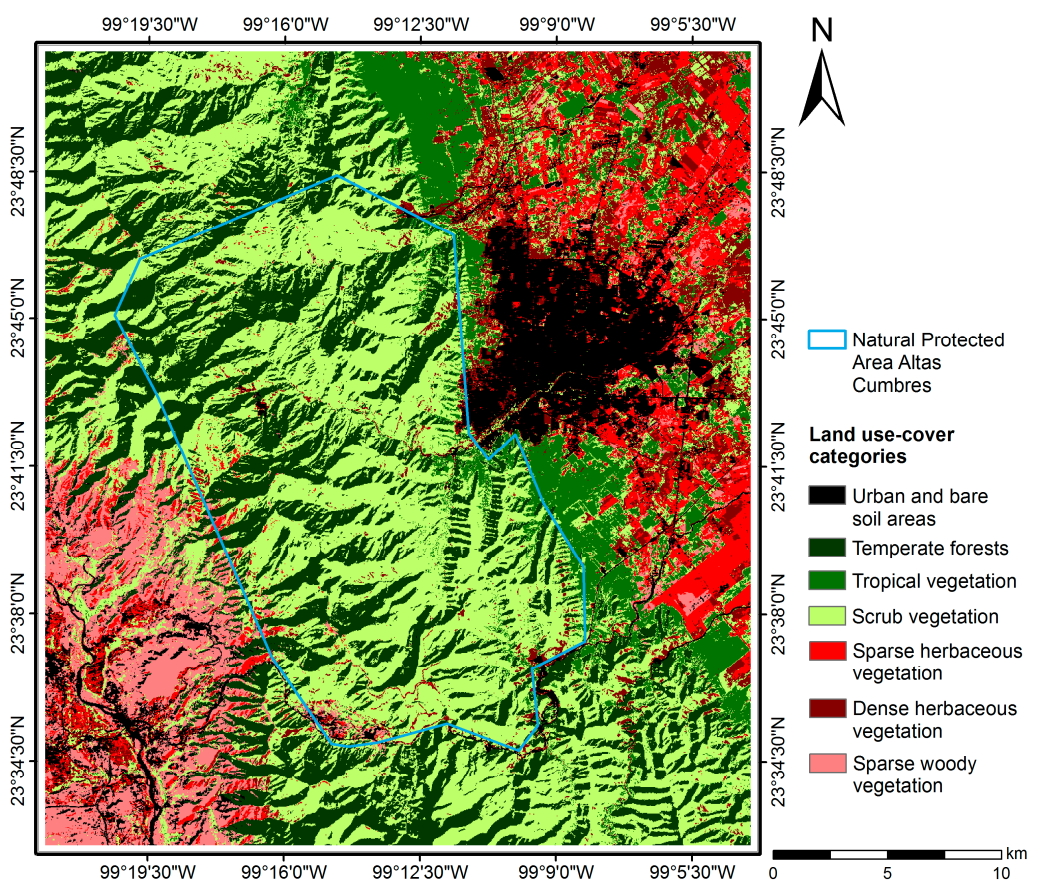

Figure A5. Land use-cover in 2015, Natural Protected Area Altas Cumbres and adjacent area. Victoria, Tamaulipas, Mexico. 


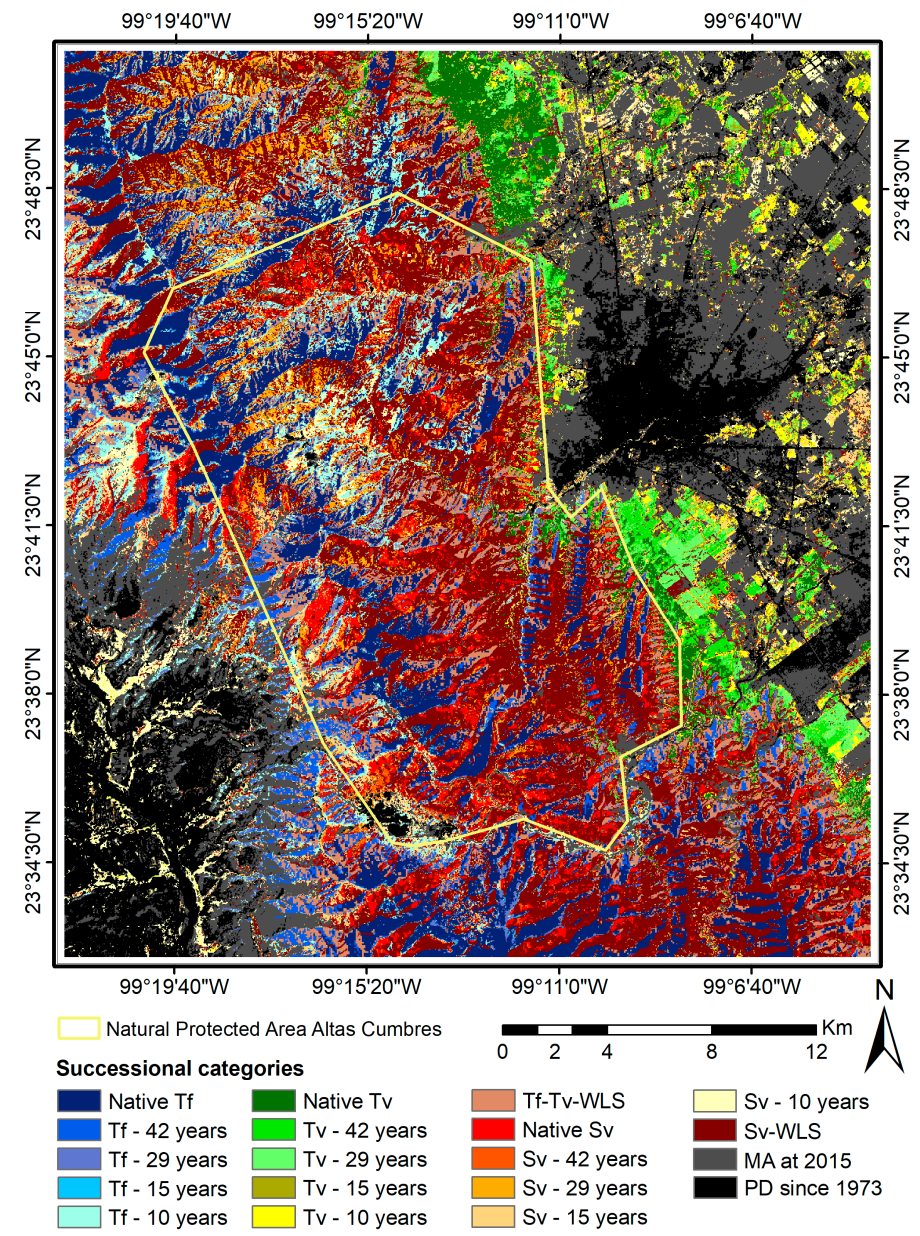

Figure A6. Successional categories of main vegetation types within the Natural Protected Area Altas Cumbres and adjacent area, 2015. Victoria, Tamaulipas, Mexico. Tf $=$ Temperate forests, $\mathrm{Tv}=$ Tropical vegetation; Tf-Tv-WLS = Temperate forests-Tropical vegetation without linear succession; $\mathrm{Sv}=$ Scrub vegetation; $\mathrm{Sv}-\mathrm{WLS}=$ Scrub vegetation without linear succession; $\mathrm{MA}=$ Modified areas; $\mathrm{PD}=$ Persistence of disturbance.

\section{References}

1. Schowalter, T.D. Insect responses to major landscape-level disturbance. Annu. Rev. Entomol. 2012, 57, 1-20. [CrossRef] [PubMed]

2. Calderon-Aguilera, L.E.; Rivera-Monroy, V.H.; Porter-Bolland, L.; Martínez-Yrízar, A.; Ladah, L.B.; Martínez-Ramos, M.; Alcocer, J.; Santiago-Pérez, A.L.; Hernandez-Arana, H.A.; Reyes-Gómez, V.M.; et al. An assessment of natural and human disturbance effects on Mexican ecosystems: Current trends and research gaps. Biodivers. Conserv. 2012, 21, 589-617. [CrossRef]

3. Fan, F.; Weng, Q.; Wang, Y. Land use and land cover change in Guangzhou, China, from 1998 to 2003, based on Landsat TM/ETM+ imagery. Sensors 2007, 7, 1323-1342. [CrossRef]

4. Soffianian, A.; Madanian, M. Monitoring land cover changes in Isfahan Province, Iran using Landsat satellite data. Environ. Monit. Assess. 2015, 187, 543. [CrossRef] [PubMed]

5. Van-Gils, H.; Armand-Ugon, A.V.L. What drives conversion of tropical forest in Carrasco Province, Bolivia? Ambio 2006, 35, 81-85. [CrossRef]

6. Foley, J.A.; DeFries, R.; Asner, G.P.; Barford, C.; Bonan, G.; Carpenter, S.R.; Chapin, F.S.; Coe, M.T.; Daily, G.C.; Gibbs, H.K.; et al. Global consequences of land use. Science 2005, 309, 570-574. [CrossRef] [PubMed]

7. Kalacska, M.E.R.; Sánchez-Azofeifa, G.A.; Calvo-Alvarado, J.C.; Rivard, B.; Quesada, M. Effects of season and successional stage on leaf area index and spectral vegetation indices in three Mesoamerican tropical dry forests. Biotropica 2005, 37, 486-496. [CrossRef] 
8. Peng, J.; Wu, J.; Yin, H.; Li, Z.; Chang, Q.; Mu, T. Rural land use change during 1986-2002 in Lijiang, China, based on remote sensing and GIS data. Sensors 2008, 8, 8201-8223. [CrossRef] [PubMed]

9. Zhou, P.; Huang, J.; Pontius, R.G.; Hong, H. Land classification and change intensity analysis in a coastal watershed of Southeast China. Sensors 2014, 14, 11640-11658. [CrossRef] [PubMed]

10. Van-Gils, H.; Batsukh, O.; Rossiter, D.; Munthali, W.; Liberatoscioli, E. Forecasting the pattern and pace of Fagus forest expansion in Majella National Park, Italy. Appl. Veg. Sci. 2008, 11, 539-546. [CrossRef]

11. Merlín-Uribe, Y.; Contreras-Hernández, A.; Astier-Calderón, M.; Jensen, O.P.; Zaragoza, R.; Zambrano, L. Urban expansion into a Protected Natural Area in Mexico City: Alternative management scenarios. J. Environ. Plan. Manag. 2012, 56, 398-411. [CrossRef]

12. Camacho-Sanabria, J.M.; Juan-Pérez, J.I.; Pineda-Jaimes, N.B. Modeling of land use/cover changes: Prospective scenarios in the Estado de Mexico. Case study-Amanalco de Becerra. Rev. Chapingo Ser. Cienc. For. Ambient. 2015, 21, 203-220. [CrossRef]

13. Cruz-Huerta, C.; González-Guillén, M.J.; Martínez-Trinidad, T.; Escalona-Maurice, M.J. Modeling land-use change and future deforestation in two spatial scales. Rev. Chapingo Ser. Cienc. For. Ambient. 2015, 21, 137-156. [CrossRef]

14. Hansen, M.C.; Stehman, S.V.; Potapov, P.V.; Loveland, T.R.; Townshend, J.R.G.; DeFries, R.S.; Pittman, K.W.; Arunarwati, B.; Stolle, F.; Steininger, M.K.; et al. Humid tropical forest clearing from 2000 to 2005 quantified by using multitemporal and multiresolution remotely sensed data. Proc. Natl. Acad. Sci. USA 2008, 105, 9439-9444. [CrossRef] [PubMed]

15. Badreldin, N.; Goossens, R. Monitoring land use/land cover change using multi-temporal Landsat satellite images in an arid environment: A case study of El-Arish, Egypt. Arab. J. Geosci. 2013, 7, 1671-1681. [CrossRef]

16. Jong, R.D.; Verbesselt, J.; Zeileis, A.; Schaepman, M.E. Shifts in global vegetation activity trends. Remote Sens. 2013, 5, 1117-1133. [CrossRef]

17. Adhikari, S.; Southworth, J.; Nagendra, H. Understanding forest loss and recovery: A spatiotemporal analysis of land change in and around Bannerghatta National Park, India. J. Land Use Sci. 2014, 10, 402-424. [CrossRef]

18. Waylen, P.; Southworth, J.; Gibbes, C.; Tsai, H. Time series analysis of land cover change: Developing statistical tools to determine significance of land cover changes in persistence analyses. Remote Sens. 2014, 6, 4473-4497. [CrossRef]

19. Wondrade, N.; Dick, Ø.B.; Tveite, H. Gis based mapping of land cover changes utilizing multi-temporal remotely sensed image data in Lake Hawassa Watershed, Ethiopia. Environ. Monit. Assess. 2014, 186, 1765-1780. [CrossRef] [PubMed]

20. Nagendra, H.; Lucas, R.; Honrado, J.P.; Jongman, R.H.G.; Tarantino, C.; Adamo, M.; Mairota, P. Remote sensing for conservation monitoring: Assessing protected areas, habitat extent, habitat condition, species diversity, and threats. Ecol. Indic. 2013, 33, 45-59. [CrossRef]

21. Lucas, R.; Blonda, P.; Bunting, P.; Jones, G.; Inglada, J.; Arias, M.; Kosmidou, V.; Petrou, Z.I.; Manakos, I.; Adamo, M.; et al. The earth observation data for habitat monitoring (EODHaM) system. Int. J. Appl. Earth Obs. Geoinf. 2015, 37, 17-28. [CrossRef]

22. Vieira, I.C.G.; Almeida, A.S.D.; Davidson, E.A.; Stone, T.A.; Carvalho, C.J.R.D.; Guerrero, J.B. Classifying successional forests using Landsat spectral properties and ecological characteristics in Eastern Amazonia. Remote Sens. Environ. 2003, 87, 470-481. [CrossRef]

23. Arroyo-Mora, J.P.; Sánchez-Azofeifa, G.A.; Kalacska, M.E.R.; Rivard, B. Secondary forest detection in a neotropical dry forest landscape using Landsat 7 ETM+ and IKONOS imagery. Biotropica 2005, 37, 497-507. [CrossRef]

24. Mas, J.-F.; Velázquez, A.; Díaz-Gallegos, J.R.; Mayorga-Saucedo, R.; Alcántara, C.; Bocco, G.; Castro, R.; Fernández, T.; Pérez-Vega, A. Assessing land use/cover changes: A nationwide multidate spatial database for Mexico. Int. J. Appl. Earth Obs. Geoinf. 2004, 5, 249-261. [CrossRef]

25. Vergés, F.A.R.; Damián, J.L.P.; Bocco, G. Cambio de uso del suelo y vegetación en la Península de Baja California, México. Investig. Geogr. Bol. Inst. Geogr. UNAM 2008, 67, 39-58.

26. Trucíos-Caciano, R.; Rivera-González, M.; Delgado-Ramírez, G.; Estrada-Ávalos, J.; Cerano-Paredes, J. Analysis of land use change in San Cristóbal de las Casas. Rev. Chapingo Ser. Zon. Áridas 2013, 12, 45-50. [CrossRef] 
27. Ramírez-Delgado, J.P.; Christman, Z.; Schmook, B. Deforestation and fragmentation of seasonal tropical forests in the Southern Yucatán, Mexico (1990-2006). Geocarto Int. 2014, 29, 822-841. [CrossRef]

28. García-Frapolli, E.; Ayala-Orozco, B.; Bonilla-Moheno, M.; Espadas-Manrique, C.; Ramos-Fernández, G. Biodiversity conservation, traditional agriculture and ecotourism: Land cover/land use change projections for a Natural Protected Area in the Northeastern Yucatan Peninsula, Mexico. Landsc. Urban Plan. 2007, 83, 137-153. [CrossRef]

29. Sánchez-Cordero, V.; Figueroa, F. La efectividad de las reservas de la biosfera en México para contener procesos de cambio en el uso del suelo y la vegetación. In Hacia una Cultura de Conservación de la Diversidad Biológica; M3M: Monografías Tercer Milenio; Halffter, G., Guevara, S., Melic, A., Eds.; S.E.A.: Zaragoza, España, 2007; Volume 6, pp. 161-171.

30. Bezaury-Creel, J.; Gutiérrez-Carbonell, D.; Remolina, J.F. Áreas naturales protegidas y desarrollo social en México. Cap. Nat. Mex. 2009, 2, 385-431.

31. Hernández-Rivera, M.G.; Torres-Hernández, L. Análisis de dos áreas naturales protegidas en relación con el crecimiento del área metropolitana de Xalapa, Veracruz. Investig. Geogr. Bol. Inst. Geogr. UNAM 2015, 87, 51-61. [CrossRef]

32. Figueroa, F.; Sánchez-Cordero, V. Effectiveness of natural protected areas to prevent land use and land cover change in Mexico. Biodivers. Conserv. 2008, 17, 3223-3240. [CrossRef]

33. Herrera-Izaguirre, J.A.; Lope-Díaz, L.H.; García-Govea, M.; Manguin-Guixeras, V.; Escobedo-Carreón, R.A. Áreas naturales protegidas en el estado de Tamaulipas: ¿Por quién están protegidas? Rev. Cient. Biol. Agropecu. Tuxpan 2014, 2, 111-116.

34. Blackman, A.; Pfaff, A.; Robalino, J. Paper park performance: Mexico's natural protected areas in the $1990 \mathrm{~s}$. Glob. Environ. Chang. 2015, 31, 50-61. [CrossRef]

35. Martínez-Ramos, M.; Ortiz-Rodríguez, I.A.; Piñero, D.; Dirzo, R.; Sarukhán, J. Anthropogenic disturbances jeopardize biodiversity conservation within tropical rainforest reserves. Proc. Natl. Acad. Sci. USA 2016, 113, 5323-5328. [CrossRef] [PubMed]

36. Jones, D.A.; Hansen, A.J.; Bly, K.; Doherty, K.; Verschuyl, J.P.; Paugh, J.I.; Carle, R.; Story, S.J. Monitoring land use and cover around parks: A conceptual approach. Remote Sens. Environ. 2009, 113, 1346-1356. [CrossRef]

37. Andrade, G.S.M.; Rhodes, J.R. Protected areas and local communities: An inevitable partnership toward successful conservation strategies? Ecol. Soc. 2012, 17, 1-16. [CrossRef]

38. Morrone, J.J.; Márquez, J. Biodiversity of Mexican terrestrial arthropods (Arachnida and Hexapoda): A biogeographical puzzle. Acta Zool. Mex. 2008, 24, 15-41.

39. Comisión Nacional para el Conocimiento y Uso de la Biodiversidad; Comisión Nacional de Áreas Naturales Protegidas; The Nature Conservancy-Programa México; Pronatura. Sitios Prioritarios Terrestres Para la Conservación de la Biodiversidad. Escala 1:1,000,000; CONABIO: Distrito Federal, Mexico, 2007. Available online: http:/ / www.conabio.gob.mx/informacion/metadata/gis/spt1mgw.xml?_xsl=/db/metadata/xsl/ fgdc_html.xsl\&_indent=no (accessed on 22 September 2016).

40. Bray, D.B. Forest cover dynamics and forest transitions in Mexico and Central America: Towards a "great restoration"? In Reforesting Landscapes: Linking Pattern and Process; Nagendra, H., Southworth, J., Eds.; Springer: Dordrecht, The Netherlands, 2010; pp. 85-120.

41. Vargas-Márquez, F; Maza-Elvira, R.D.L.; Pont-Lalli, R.M.D. Áreas Naturales Protegidas de México Con Decretos Estatales; Instituto Nacional de Ecología, Comisión Nacional de Áreas Naturales Protegidas, SEMARNAT: Distrito Federal, Mexico, 2001; p. 1014.

42. Órgano del Gobierno Constitucional del Estado Libre y Soberano de Tamaulipas. DECRETO Gubernamental Mediante el Cual se Aprueba el PROGRAMA De MANEJO Del Área Natural Protegida "Altas Cumbres", Localizada en los Municipios de Jaumave y Victoria, Tamaulipas; Periódico Oficial del Estado de Tamaulipas, Tomo CXL; Secretaría General de Gobierno: Ciudad Victoria, Mexico, 2015; pp. 2-75.

43. Almaguer-Sierra, P.; Barrientos-Lozano, L.; Blanco-Macías, F.; Guevara-Guerrero, G.; Sánchez-Meza, A.D. Evaluación climática del Área Natural Protegida "Altas Cumbres", Victoria, Tamaulipas, México. Tecnointelecto 2011, 8, 1-9. 
44. García-Morales, L.J.; Estrada-Castillón, A.E.; García-Jiménez, J.; Villarreal-Quintanilla, J.A.; Cantú-Ayala, C.; Jurado-Ybarra, E.; Vargas-Vázquez, V.A. Florística y vegetación del Área Natural Protegida Altas Cumbres, Tamaulipas, México. In Biodiversidad Tamaulipeca Volumen 2, Número 1; Correa-Sandoval, A., Horta-Vega, J.V., García-Jiménez, J., Barrientos-Lozano, L., Eds.; Tecnológico Nacional de México, Instituto Tecnológico de Ciudad Victoria: Ciudad Victoria, Mexico, 2014; pp. 15-73.

45. García, E. Modificaciones al Sistema de Clasificación Climática de Köppen, Quinta Edición; Instituto de Geografía, UNAM: Distrito Federal, Mexico, 2004; p. 90.

46. Treviño-Carreón, J.; Valiente-Banuet, A. La vegetación de Tamaulipas y sus principales asociaciones vegetales. In Biodiversidad Tamaulipeca Vol. 1; Barrientos-Lozano, L., Correa-Sandoval, A., Horta-Vega, J.V., García-Jiménez, J., Eds.; Dirección General de Educación Superior Tecnológica, Instituto Tecnológico de Ciudad Victoria: Ciudad Victoria, Mexico, 2005; pp. 22-46.

47. Gutman, G.; Huang, C.; Chander, G.; Noojipady, P.; Masek, J.G. Assessment of the NASA-USGS Global Land Survey (GLS) datasets. Remote Sens. Environ. 2013, 134, 249-265. [CrossRef]

48. Global Land Cover Facility (GLCF), Global Land Survey (GLS), 2016. Available online: http://www. landcover.org/data/gls/ (accessed on 10 September 2016).

49. USGS Global Visualization Viewer (GLOVIS), 2016. United States Geological Survey Earth Resources Observation Systems. Available online: http://glovis.usgs.gov/ (accessed on 10 September 2016).

50. USGS. Landsat 8 (L8) Data Users Handbook Version 2.0. EROS, Sioux Falls, South Dakota. 2016. Available online: https: / /landsat.usgs.gov/landsat-8-18-data-users-handbook (accessed on 13 September 2016).

51. ENVI. ENVI Version 5.0; Exelis Visual Information Solutions, Inc.: Boulder, CO, USA, 2012.

52. Eastman, J.R. Idrisi Selva Tutorial. Manual Version 17; Clark Labs, Clark University: Worcester, MA, USA, 2012; p. 354.

53. INEGI. INE INEGI, 1997. Uso Del Suelo y Vegetación, Escala 1:250,000, Serie I (Continuo Nacional); Instituto Nacional de Ecología (INE)—Dirección de Ordenamiento Ecológico General e Instituto Nacional de Estadística, Geografía e Informática (INEGI); INEGI: Aguascalientes, Mexico, 1997.

54. INEGI. INEGI, 2001. Uso Del Suelo y Vegetación, Escala 1:250,000, Serie II (Continuo Nacional); Dirección General de Geografía, Instituto Nacional de Estadística, Geografía e Informática (INEGI): Aguascalientes, Mexico, 2001.

55. INEGI. INEGI, 2005. Uso Del Suelo y Vegetación, Escala 1:250,000, Serie III (Continuo Nacional); Dirección General de Geografía, Instituto Nacional de Estadística, Geografía e Informática (INEGI): Aguascalientes, Mexico, 2005.

56. INEGI. INEGI, 2009. Uso Del Suelo y Vegetación, Escala 1:250,000, Serie IV (Continuo Nacional); Dirección General de Geografía, Instituto Nacional de Estadística, Geografía e Informática (INEGI): Aguascalientes, Mexico, 2009.

57. INEGI. INEGI, 2013. Conjunto De Datos Vectoriales De Uso Del Suelo y Vegetación Escala 1:250,000, Serie V (Capa Unión); Instituto Nacional de Estadística y Geografía (INEGI): Aguascalientes, Mexico, 2013.

58. Cohen, J. A coefficient of agreement for nominal scales. Educ. Psychol. Meas. 1960, 20, 37-46. [CrossRef]

59. Canizales-Velázquez, P.A.; Alanís-Rodríguez, E.; Aranda-Ramos, R.; Mata-Balderas, J.M.; Jiménez-Pérez, J.; Alanís-Flores, G.; Uvalle-Sauceda, J.I.; Ruiz-Bautista, M.G. Caracterización estructural del matorral submontano de la Sierra Madre Oriental, Nuevo León, México. Rev. Chapingo Ser. Cien. For. Ambient. 2009, 15, 115-120.

60. Esri. ArcGIS 10.2 for Desktop. 1999-2013 Esri Inc.; Environmental Systems Research Institute: Redlands, CA, USA, 2013.

61. Anderson, J.R.; Hardy, E.E.; Roach, J.T.; Witmer, R.E. A Land Use and Land Cover Classification System for Use with Remote Sensor Data; United States Government Printing Office: Washington, DC, USA, 1976; p. 28.

62. Reis, S. Analyzing land use/land cover changes using remote sensing and GIS in Rize, North-East Turkey. Sensors 2008, 8, 6188-6202. [CrossRef] [PubMed]

63. Bailey, K.M.; McCleery, R.A.; Binford, M.W.; Zweig, C. Land-cover change within and around protected areas in a biodiversity hotspot. J. Land Use Sci. 2015, 11, 154-176. [CrossRef]

64. Rahman, M.T. Detection of land use/land cover changes and urban sprawl in Al-Khobar, Saudi Arabia: An analysis of multi-temporal remote sensing data. ISPRS Int. J. Geoinf. 2016, 5, 15. [CrossRef] 
65. Johnson, E.A.; Miyanishi, K. Disturbance and succession. In Plant Disturbance Ecology: The Process and the Response; Johnson, E.A., Miyanishi, K., Eds.; Elsevier Academic Press: Burlington, MA, USA, 2007; pp. 1-14.

66. Pickett, S.T.A.; Cadenasso, M.L.; Meiners, S.J. Ever since clements: From succession to vegetation dynamics and understanding to intervention. Appl. Veg. Sci. 2008, 12, 9-21. [CrossRef]

67. Pulsford, S.A.; Lindenmayer, D.B.; Driscoll, D.A. A succession of theories: Purging redundancy from disturbance theory. Biol. Rev. Camb. Philos. Soc. 2016, 91, 148-167. [CrossRef] [PubMed]

68. DeWalt, S.J.; Maliakal, S.K.; Denslow, J.S. Changes in vegetation structure and composition along a tropical forest chronosequence: Implications for wildlife. For. Ecol. Manag. 2003, 182, 139-151. [CrossRef]

69. Walker, L.R.; Wardle, D.A.; Bardgett, R.D.; Clarkson, B.D. The use of chronosequences in studies of ecological succession and soil development. J. Ecol. 2010, 98, 725-736. [CrossRef]

70. Meiners, S.J.; Cadotte, M.W.; Fridley, J.D.; Pickett, S.T.A.; Walker, L.R. Is successional research nearing its climax? New approaches for understanding dynamic communities. Funct. Ecol. 2015, 29, 154-164. [CrossRef]

71. Chazdon, R.L.; Letcher, S.G.; Breugel, M.V.; Martínez-Ramos, M.; Bongers, F.; Finegan, B. Rates of change in tree communities of secondary Neotropical forests following major disturbances. Philos. Trans. R. Soc. B Biol. Sci. 2007, 362, 273-289. [CrossRef] [PubMed]

72. Guariguata, M.R.; Ostertag, R. Neotropical secondary forest succession: Changes in structural and functional characteristics. For. Ecol. Manag. 2001, 148, 185-206. [CrossRef]

73. Delang, C.O.; Li, W.M. Ecological Succession on Fallowed Shifting Cultivation Fields: A Review of the Literature; Springer: Dordrecht, The Netherlands, 2013; p. 127.

74. Zermeño-Hernández, I.; Méndez-Toribio, M.; Siebe, C.; Benítez-Malvido, J.; Martínez-Ramos, M. Ecological disturbance regimes caused by agricultural land uses and their effects on tropical forest regeneration. Appl. Veg. Sci. 2015, 18, 443-455. [CrossRef]

75. Burgos, A.; Maass, J.M. Vegetation change associated with land-use in tropical dry forest areas of western Mexico. Agric. Ecosyst. Environ. 2004, 104, 475-481. [CrossRef]

76. Almazán-Núñez, R.C.; Arizmendi, M.D.C.; Eguiarte, L.E.; Corcuera, P. Changes in composition, diversity and structure of woody plants in successional stages of tropical dry forest in southwest Mexico. Rev. Mex. Biodivers. 2012, 83, 1096-1109. [CrossRef]

77. Almazán-Núñez, R.C.; Corcuera, P.; Parra-Juárez, L.; Jiménez-Hernández, J.; Charre, G.M. Changes in structure and diversity of woody plants in a secondary mixed pine-oak forest in the Sierra Madre del Sur of Mexico. Forests 2016, 7, 90. [CrossRef]

78. Alanís-Rodríguez, E.; Jiménez-Pérez, J.; Valdecantos-Dema, A.; Pando-Moreno, M.; Aguirre-Calderón, O.; Treviño-Garza, E.J. Caracterización de regeneración leñosa post-incendio de un ecosistema templado del Parque Ecológico Chipinque, México. Rev. Chapingo Ser. Cien. For. Ambient. 2011, 17, 31-39. [CrossRef]

79. Lebrija-Trejos, E.; Bongers, F.; Pérez-García, E.A.; Meave, J.A. Successional change and resilience of a very dry tropical deciduous forest following shifting agriculture. Biotropica 2008, 40, 422-431. [CrossRef]

80. Norden, N.; Angarita, H.A.; Bongers, F.; Martínez-Ramos, M.; Granzow-de la Cerda, I.; Breugel, M.V.; Lebrija-Trejos, E.; Meave, J.A.; Vandermeer, J.; Williamson, G.B.; et al. Successional dynamics in neotropical forests are as uncertain as they are predictable. Proc. Natl. Acad. Sci. USA 2015, 112, 8013-8018. [CrossRef] [PubMed]

81. Berlanga-Robles, C.A.; García-Campos, R.R.; López-Blanco, J.; Ruiz-Luna, A. Patrones de cambio de coberturas y usos del suelo en la región Costa Norte de Nayarit (1973-2000). Investig. Geogr. Bol. Inst. Geogr. (UNAM) 2010, 72, 7-22.

82. Román-Dañobeytia, F.J.; Levy-Tacher, S.I.; Macario-Mendoza, P.; Zúñiga-Morales, J. Redefining secondary forests in the Mexican forest code: Implications for management, restoration, and conservation. Forests 2014, 5, 978-991. [CrossRef]

83. García-Hernández, J.; Jurado, E. Caracterización del matorral con condiciones prístinas en Linares N.L., México. Ra Ximhai 2008, 4, 1-21.

84. Mora-Olivo, A.; Alanís-Rodríguez, E.; Marroquín-Castillo, J.J.; Sarmiento-Muñoz, T.I.; Martínez-Ávalos, J.G.; Garza-Ocañas, F.; Torres-Castillo, J.A. Structure and diversity of a submontane scrub community in Tamaulipas, Mexico. Interciencia 2016, 41, 769-773.

85. Alanís-Rodríguez, E.; Jiménez-Pérez, J.; González-Tagle, M.A.; Yerena-Yamallel, J.I.; Cuellar-Rodríguez, G.; Mora-Olivo, A. Análisis de la vegetación secundaria del matorral espinoso tamaulipeco, México. Phyton (B. Aires) 2013, 82, 185-191. 
86. Navar, J.; Rodriguez-Flores, F.D.J.; Dominguez-Calleros, P.A.; Perez-Verdin, G. Diversity-productivity relationship in the Northeastern Tamaulipan thornscrub forest of Mexico. Int. J. Ecol. 2014, 2014, 1-11. [CrossRef]

87. Lebrija-Trejos, E.; Pérez-García, E.A.; Meave, J.A.; Poorter, L.; Bongers, F. Environmental changes during secondary succession in a tropical dry forest in Mexico. J. Trop. Ecol. 2011, 27, 477-489. [CrossRef]

88. Denslow, J.S.; Sandra, G.-G. Variation in stand structure, light and seedling abundance across a tropical moist forest chronosequence, Panama. J. Veg. Sci. 2000, 11, 201-212. [CrossRef]

89. Aubin, I.; Ouellette, M.-H.; Legendre, P.; Messier, C.; Bouchard, A. Comparison of two plant functional approaches to evaluate natural restoration along an old-field-Deciduous forest chronosequence. J. Veg. Sci. 2009, 20, 185-198. [CrossRef]

90. Lohbeck, M.; Poorter, L.; Martínez-Ramos, M.; Rodriguez-Velázquez, J.; Breugel, M.V.; Bongers, F. Changing drivers of species dominance during tropical forest succession. Funct. Ecol. 2014, 28, 1052-1058. [CrossRef]

91. Whitfeld, T.J.S.; Lasky, J.R.; Damas, K.; Sosanika, G.; Molem, K.; Montgomery, R.A. Species richness, forest structure, and functional diversity during succession in the New Guinea lowlands. Biotropica 2014, 46, 538-548. [CrossRef]

92. Craven, D.; Hall, J.S.; Berlyn, G.P.; Ashton, M.S.; Breugel, M.V. Changing gears during succession: Shifting functional strategies in young tropical secondary forests. Oecologia 2015, 179, 293-305. [CrossRef] [PubMed]

(C) 2017 by the authors. Licensee MDPI, Basel, Switzerland. This article is an open access article distributed under the terms and conditions of the Creative Commons Attribution (CC BY) license (http://creativecommons.org/licenses/by/4.0/). 